\title{
Microwave assisted the short time clean synthesis of 1,3-diketones as building blocks in heterocyclic synthesis: a facile synthesis and antimicrobial evaluation of new dihydropyridine, $4 \mathrm{H}$-pyrane, dihydropyridazine, pyrimidine and pyrazole derivatives
}

\author{
Mohamed Ahmed Mahmoud Abdel Reheim ${ }^{1}$ (D) - Ibrahim Saad Abdel Hafiz ${ }^{1} \cdot$ Hend Saad Eldin Abdel Rady $^{1}$
}

Received: 21 August 2020 / Accepted: 23 October 2020 / Published online: 5 January 2021

(c) The Author(s) 2021

\section{Abstract}

The compounds bearing naphthalene moiety can be used as medical preparations because of their wide spectrum of biological activity and low toxicity. In this study, a new series of azoles or azines were synthesized from the reaction of the key intermediate 1-(1-hydroxynaphthalen-2-yl)-3-phenylpropane-1,3-dione $\mathbf{3}$ with a variety of electrophilic and nucleophilic reagents under a variety of mild conditions. The chemical structures of these compounds were confirmed by various spectroscopic methods such as (IR, ${ }^{1} \mathrm{H}-\mathrm{NMR},{ }^{13} \mathrm{C}-\mathrm{NMR}$, mass spectra and elemental analyses). The prepared compounds were screened in vitro for their anti-microbial activity against some species of Gram-positive bacteria (Staphylococcus aureus and Bacillus subtilis) and Gram-negative bacteria (Escherichia coli and Pseudomonas aeuroginosa). Anti-fungal activities of the compounds were tested against yeast and mycelial fungi,Candida albicans and Aspergillus flavus. The antimicrobial activity of this series was showed either weak or moderate activities.

Graphic abstract<smiles>Oc1cccc2ccccc12</smiles><smiles>CCOC(=O)CC(=O)c1ccccc1</smiles>

Keywords Heterocycles $\cdot$ Microwave irradiation $\cdot$ Spectral characteristics $\cdot$ Antimicrobial activities

Mohamed Ahmed Mahmoud Abdel Reheim dr.mohamedabdelreheim@gmail.com

1 Department of Chemistry, Faculty of Science, Arish University, Arish 45511, Egypt

\section{Introduction}

According to the literature survey, heterocyclic compounds containing nitrogen, sulfur and oxygen atom are found to possess a varity of biological activities. Among them, pyrazoles, cyanopyridines, pyrimidinethiones. pyranes or their fused ring systems and pyridazine are found to exhibit a wide 
spectrum of biological activities. Various biological applications have been reported for pyrazoles such as anti-viral [1], anti-cancer [2], anti-microbial [3], anti-inflammatory [4], anti-depressant [5] anti-convulsant [6] analgesic and antiplatelet [7, 8]. Cyanopyridine derivatives have attracted considerable attention as they appeared of interest to possess anti-cancer [9], anti-convulsant [10] and anti-microbial [11]. Pyrimidinethiones have been found to possess anti-tubercular [12]. Pyrane and fused 4H-pyrane derivatives have attracted a great interest owing to their anti-microbial [13, 14], anti-oxidant [15], inhibitors of influenza virus sialidases [16], mutagenic activity [17], anti-cancer [18] and anti-viral [19]. Also, Pyridazine ring is a nucleus of a many of drugs available in the market like cadralazine (anti-hypertensive), minaprine (anti-depressant), hydralazine (smooth muscle relaxant), pipofezine (tricyclic antidepressant) [20,21]. The aim of the present work, was to synthesize new pyrazole, pyridine, pyrimidine, pyrane and pyridazine derivatives by using 1-(1-hydroxynaphthalen-2-yl)-3-phenylpropane1,3-dione 3 as the key starting material. Followed by antimicrobial evaluations of newly synthesized products were done. In general, the novel synthesized compounds showed a moderate antimicrobial activity against the previously mentioned microorganisms.

\section{Results and discussion}

Organic synthesis by using microwave irradiation (MW) is a new and interesting technique and is becoming popular now. The reactions under microwave irradiation take place in few minutes and no solvent is required [22-25]. In continution to our research for chemistry developments [26-29], we report here the use of microwave irradiation for the synthesis of 1-(1-hydroxynaphthalen-2-yl)-3-phenyl-propane-1,3-dione 3 in a quantitative yield (91\%) from the reaction of $\alpha$ - naphthol and ethyl benzoylacetate in the presence of zinc chloride
[30]. Rather than the expected coumarin $\mathbf{4}$ as the literature [31]. The key intermediate 3 was prepared previously in the literature [32, 33]. The structure of the latter product $\mathbf{3}$ was established on the basis of its elemental analyses and spectral data and chemical transformation. Thus, the infrared spectrum of compound 3 revealed an absorption bands at $3365,3061,2924,1720,1639 \mathrm{~cm}^{-1}$ for hydroxyl, aromatic, aliphatic and carbonyl function groups, respectively. The ${ }^{1} \mathrm{H}-$ NMR spectrum of compound $\mathbf{3}$ showed the following signals at $\delta=4.49\left(\mathrm{~s}, 2 \mathrm{H}, \mathrm{CH}_{2}\right), 7.20-8.68(\mathrm{~m}, 11 \mathrm{H}$, aromatic $\mathrm{H})$, $8.69(\mathrm{~s}, 1 \mathrm{H}, \mathrm{OH})$. Also, the mass spectrum of compound 3 is in agreement with the proposed structure, its showed a molecular ion peak at $m / z=290\left(\mathrm{M}^{+}\right)$corresponding to a molecular formula $\mathrm{C}_{19} \mathrm{H}_{14} \mathrm{O}_{3}$ (Scheme 1).

The active methylene group in compound $\mathbf{3}$ was exploited to synthesize some novel heterocyclic compounds by its reaction with some electophilic and nucleophilic reagents. Thus, the reaction of compound $\mathbf{3}$ with dimethylformamide-dimethylacetal (DMF-DMA) in dioxane afforded the enaminone derivative $\mathbf{5}$ in a good yield as demonstrated in (Scheme 2). Establishing the structure 5 was based on its elemental analyses and spectral data. Thus, the ${ }^{1} \mathrm{H}-\mathrm{NMR}$ spectrum of compound $\mathbf{5}$ showed the following signals, a singlet signal at $\delta=3.00 \mathrm{ppm}$ assigned to $\mathrm{N}\left(\mathrm{CH}_{3}\right)_{2}$, a singlet signal at $\delta=7.19 \mathrm{ppm}$ assigned to oleffinic proton, a multiplet signals at $\delta=7.64-8.67 \mathrm{ppm}$ assigned to aromatic protons and a singlet signal at $\delta=8.68 \mathrm{ppm}$ assigned to hydroxyl group. Moreover, the mass spectrum revealed a molecular ion peak at $m / z=345\left(\mathrm{M}^{+}\right)$related to a molecular formula $\mathrm{C}_{22} \mathrm{H}_{19} \mathrm{NO}_{3}$. Also, when compound $\mathbf{3}$ was alkylated with triethylorthoformate in refluxing acetic anhydride afforded the ethoxymethylene derivative $\mathbf{6}$. Establishing the structure $\mathbf{6}$ was based on spectral data in addition of elemental analyses. So, its ${ }^{1} \mathrm{H}-\mathrm{NMR}$ spectrum in DMSO- $\mathrm{d}_{6}$ revealed the following signals at $\delta=1.11\left(\mathrm{t}, 3 \mathrm{H}, \mathrm{CH}_{3}\right), 4.19\left(\mathrm{q}, 2 \mathrm{H}, \mathrm{CH}_{2}\right), 6.33$ (s, $1 \mathrm{H}, \mathrm{CH}$-oleffinic), 7.29-8.23 $(\mathrm{m}, 11 \mathrm{H}$, aromatic $\mathrm{H}), 8.68$ $(\mathrm{s}, 1 \mathrm{H}, \mathrm{OH})$. The mass spectrum of the same product is in
Scheme 1 The synthesis route of compound $\mathbf{3}$

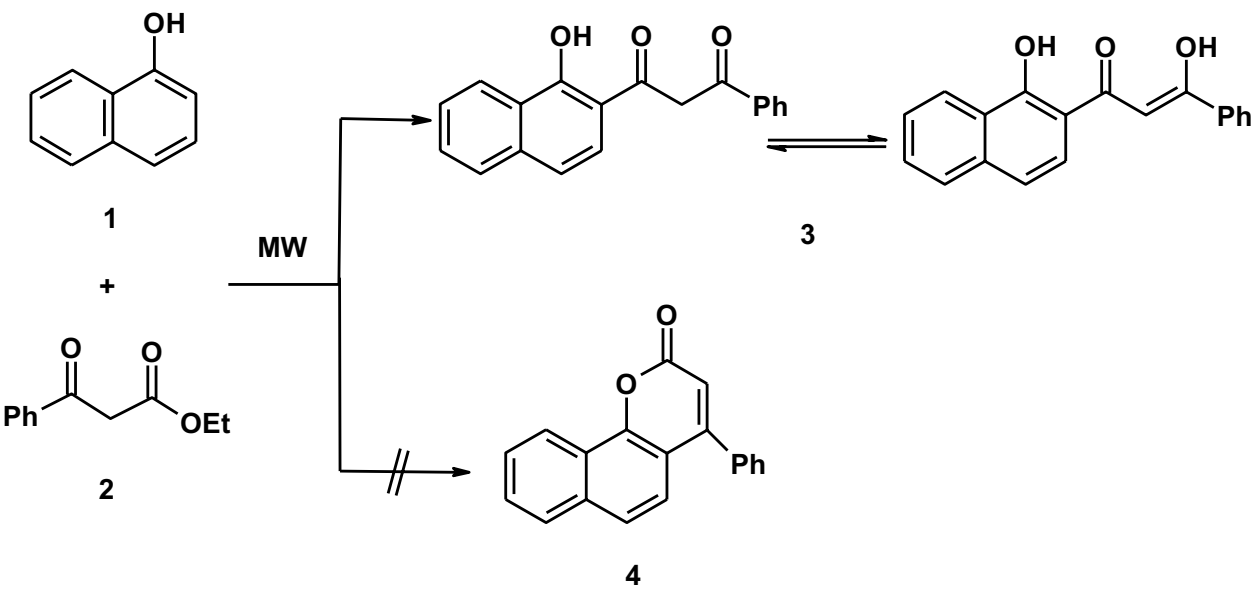




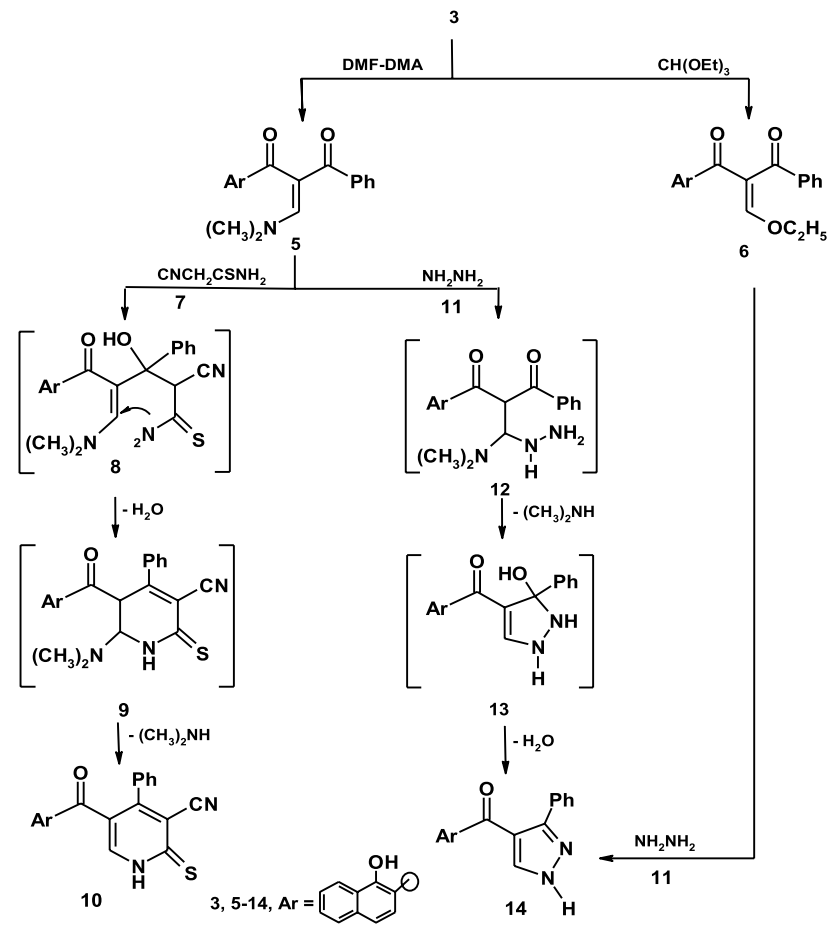

Scheme 2 Synthetic route to pyridinethione and pyrazoles

accordance with the proposed structure. Thus, it showed a molecular ion peak at $m / z=346\left(\mathrm{M}^{+}\right)$.

Compound 5 readily reacted with cyanothioacetamide 7 as example of active methylene reagents in refluxing ethanolic sodium ethoxide yield the expected pyridinethione derivative $\mathbf{1 0}$ which established on its spectral data (IR, ${ }^{1} \mathrm{H}-\mathrm{NMR}$, mass spectra, ${ }^{13} \mathrm{C}-\mathrm{NMR}$ and elemental analyses). So, its mass spectrum revealed a molecular ion peak at $m / z=384\left(\mathbf{M}^{+}+2\right)$ corresponding to a molecular formula $\mathrm{C}_{23} \mathrm{H}_{14} \mathrm{~N}_{2} \mathrm{O}_{2} \mathrm{~S}$. Formation of pyridinethione $\mathbf{1 0}$ is believed to be proceed via initial addition of active methylene moiety in cyanothioacetamide on the $\pi$-bond system of the carbonyl group of $\mathbf{5}$ to afford the Michael adduct $\mathbf{8}$ that cyclizes by losing water molecule under the same reaction condition to give intermediate 9 which eliminate dimethylamine molecule to yield the final structure $\mathbf{1 0}$ as demonstrated in (Scheme 2) [34]. Furthermore, the behavior of enaminone $\mathbf{5}$ toward binucleophilic reagents was also investigated. Thus, when compound $\mathbf{5}$ was allowed to react with hydrazine hydrate a compound with a molecular formula $\mathrm{C}_{20} \mathrm{H}_{14} \mathrm{~N}_{2} \mathrm{O}_{2}=314\left(\mathrm{M}^{+}\right)$is formed which may be formulated as structure $\mathbf{1 4}$ based on spectroscopic data. Thus, the ${ }^{1} \mathrm{H}-\mathrm{NMR}$ spectrum of compound 14 showed a singlet signal at $\delta=7.22$ assigned to $\mathrm{CH}$-pyrazole, a multiplet signals at $\delta=7.31-8.71$ assigned for $\mathrm{CH}$ aromatic and $\mathrm{NH}$ protons and a singlet signal at $\delta=8.73$ assigned to $\mathrm{OH}$ group. On the other hand, compound 6 was reacted with hydrazine hydrate to afford the product identical in all

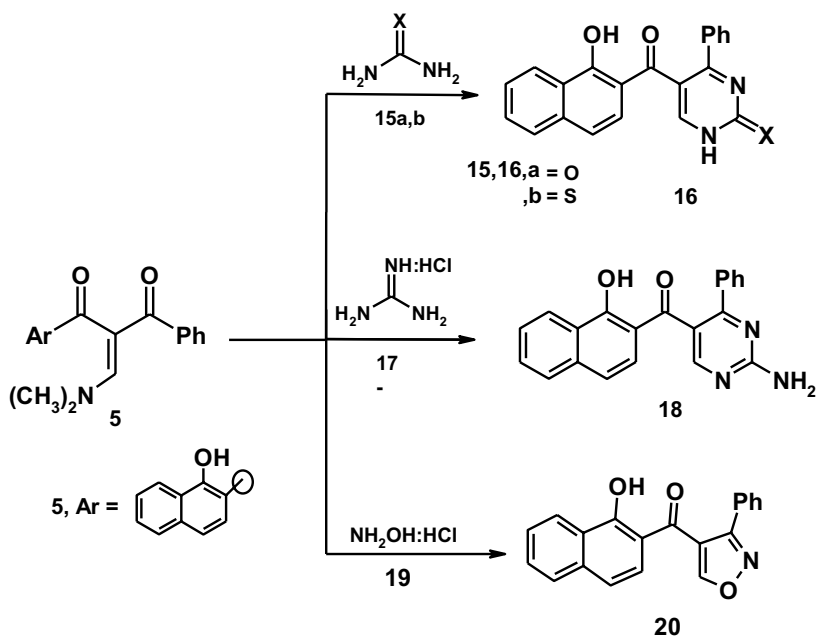

Scheme 3 Synthetic route to pyrimidine and isoxazole

respects (mp, mixed $\mathrm{mp}$, and spectral data) with those corresponding to the pyrazole derivative $\mathbf{1 4}$ as demonstrated in (Scheme 2).

Similarly, reactions of enaminone $\mathbf{5}$ with urea or thiourea to yield the expected pyrimidine derivatives $\mathbf{1 6 a}, \mathbf{b}$. Compounds 16a,b were established on its correct spectral data (IR, ${ }^{1} \mathrm{H}-\mathrm{NMR}$, mass spectra and elemental analyses). Also, enaminone 5 reacted with guanidine hydrochloride to yield the pyrimidine derivative $\mathbf{1 8}$ which established on spectral data. On the other hand, the reaction of enaminone 5 with hydroxylamine hydrochloride in ethanol containing anhydrous sodium acetate afforded the isoxazole derivative 20. The structure of compound $\mathbf{2 0}$ was established based on its elemental analyses and spectroscopic data. Thus, the ${ }^{1} \mathrm{H}-\mathrm{NMR}$ spectrum of compound $\mathbf{2 0}$ revealed the presence of a singlet signal at $\delta=7.21 \mathrm{ppm}$ corresponding to the $\mathrm{CH}$-isoxazole and a multiplet signals at $\delta=7.31-8.70 \mathrm{ppm}$ corresponding to aromatic protons and a singlet signal at $8.71 \mathrm{ppm}$ corresponding to $\mathrm{OH}$ group. The mass spectrum of compound 20 revealed a molecular ion peak at $m / z=315$ $\left(\mathrm{M}^{+}\right)$corresponding to a molecular formula $\mathrm{C}_{20} \mathrm{H}_{13} \mathrm{NO}_{3}$ as demonstrated in (Scheme 3).

3-Phenylpropane-1,3-dione derivative $\mathbf{3}$ was examined as a key precursor toward a variety of nucleophlic and electrophilic reagents aiming at exploring its synthetic potentiality. Thus, when compound $\mathbf{3}$ was reacted with hydroxylamine hydrochloride to yield the isoxazole derivative $\mathbf{2 3}$ in a good yield. Compound 23 was established based on its spectral data (IR, ${ }^{1} \mathrm{H}-\mathrm{NMR},{ }^{13} \mathrm{C}-\mathrm{NMR}$, mass spectra) and elemental analyses. The ${ }^{1} \mathrm{H}-\mathrm{NMR}$ spectrum of compound $\mathbf{2 3}$ showed a singlet signal at $\delta=7.21 \mathrm{ppm}$ assigned to $\mathrm{CH}$-isoxazole, a singlet signal at $\delta=8.69 \mathrm{ppm}$ assigned to $\mathrm{OH}$ group beside a multiplet signals at $\delta=7.32-8.54 \mathrm{ppm}$ assigned to aromatic protons. The mass spectrum showed a molecular ion peak 
at $m / z=287\left(\mathrm{M}^{+}\right)$corresponding to a molecular formula $\mathrm{C}_{19} \mathrm{H}_{13} \mathrm{NO}_{2}$ as demonstrated in (Scheme 4).

The reactivity of compound $\mathbf{3}$ toward active methylene reagents was also investigated and found to afford new pyridinone derivative. Thus, when compound $\mathbf{3}$ was reacted with malononitrile in ethanolic sodium ethoxide, a product 26 with molecular formula $\mathrm{C}_{22} \mathrm{H}_{14} \mathrm{~N}_{2} \mathrm{O}_{2}$ was obtained as the sole isolable product through the intermediates $\mathbf{2 4}$ and 25 [35]. On the other hand, the reaction of compound 3 with a mixture of malononitrile and elemental sulfur in ethanolic piperidine afforded the expected thiophene derivative 29 as demonstrated in (Scheme 5) [34]. Assignment of structure 29 for the reaction product was based on its correct elemental analyses and compatible spectroscopic data, the ${ }^{1} \mathrm{H}-\mathrm{NMR}$ of the structure revealed a singlet signal at $\delta=8.69 \mathrm{ppm}$ corresponding to $\mathrm{OH}$ group beside a multiplet signals corresponding to the aromatic protons and $\mathrm{NH}_{2}$ at $\delta=7.20-8.68 \mathrm{ppm}$. Also, the mass spectrum showed a

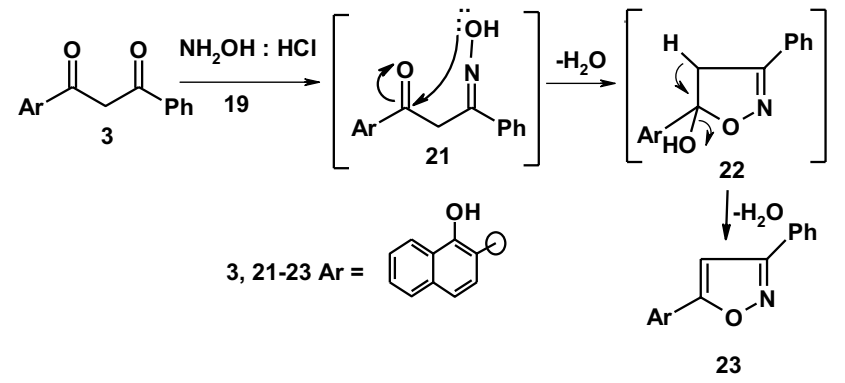

Scheme 4 The synthesis route of compound $\mathbf{2 3}$ molecular ion peak at $m / z=370\left(\mathrm{M}^{+}\right)$corresponding to a molecular formula $\mathrm{C}_{22} \mathrm{H}_{14} \mathrm{~N}_{2} \mathrm{O}_{2} \mathrm{~S}$.

One-pot reaction of a mixture of compound $\mathbf{3 1}$ and dimedone in the presence of ammonium acetate afforded the tetrahydroquinoline derivatives 35a-c. Assignment of structure $\mathbf{3 5} \mathbf{b}$ as example for the reaction product was based on its compatible spectroscopic data. Thus, its IR spectrum showed an absorption bands at $3371,3255 \mathrm{~cm}^{-1}$ for $(\mathrm{OH} /$ $\mathrm{NH}), 3059 \mathrm{~cm}^{-1}$ for (CH-arom), $2954-2835 \mathrm{~cm}^{-1}$ for $(\mathrm{CH}-$ aliph) and $1639,1620 \mathrm{~cm}^{-1}$ for $(2 \mathrm{C}=\mathrm{O})$ group. However, the ${ }^{1} \mathrm{H}-\mathrm{NMR}$ of compound $\mathbf{3 5 b}$ for example showed a singlet signals at $\delta=0.82,1.19 \mathrm{ppm}$ corresponding to $2 \mathrm{CH}_{3}$, two singlet signals at $\delta=2.70 \mathrm{ppm}$ and at $\delta=2.86 \mathrm{ppm}$ corresponding to two methylene groups of dimedone, a singlet signal at $\delta=3.70 \mathrm{ppm}$ assigned to $\mathrm{OCH}_{3}$ protons, a singlet signal at $\delta=4.49 \mathrm{ppm}$ assigned to $\mathrm{CH}$-pyridine, a singlet signal at $\delta=8.45 \mathrm{ppm}$ assigned to $\mathrm{OH}$ group beside a multiplet signals at $\delta=7.21-8.28 \mathrm{ppm}$ assigned to aromatic protons and $\mathrm{NH}$. The mass spectrum of the same compound revealed a molecular ion peak at $529\left(\mathrm{M}^{+}\right)$and a number of fragments which agree with the proposed structure. The formation of 35a-c can be understood in terms of the Michael type addition of the active methylene group in the dimedone molecule to the activated double bond in the compound $\mathbf{3 1}$ to yield the Michael adduct $\mathbf{3 3}$ and cyclized to $\mathbf{3 4}$, the intermediate 34 was oxidized by loss of water molecule to yield the final product 35 [36-38] as demonstrated in (Scheme 6).

Reactions of compound 3 with some electrophilic reagents under alkaline conditions were also investigated. Thus, 4H-pyran-3-carbonitrile derivatives 40a,b were synthesized in an excellent yield upon treatment of $\mathbf{3}$ with arylidinemalononitrile 36a-b in the presence of a catalytic amount of
Scheme 5 Synthetic route to pyridine and thiophene

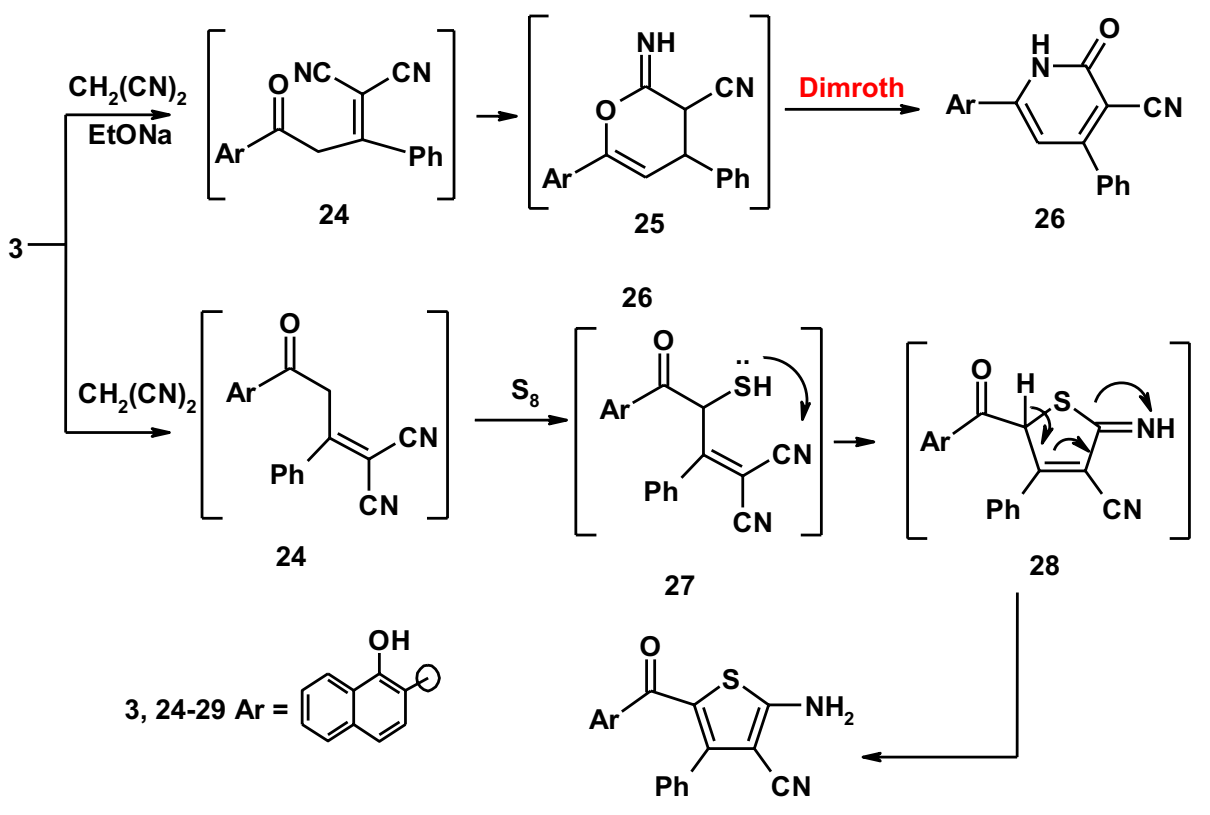

29 
Scheme 6 Synthetic route to fused pyridine

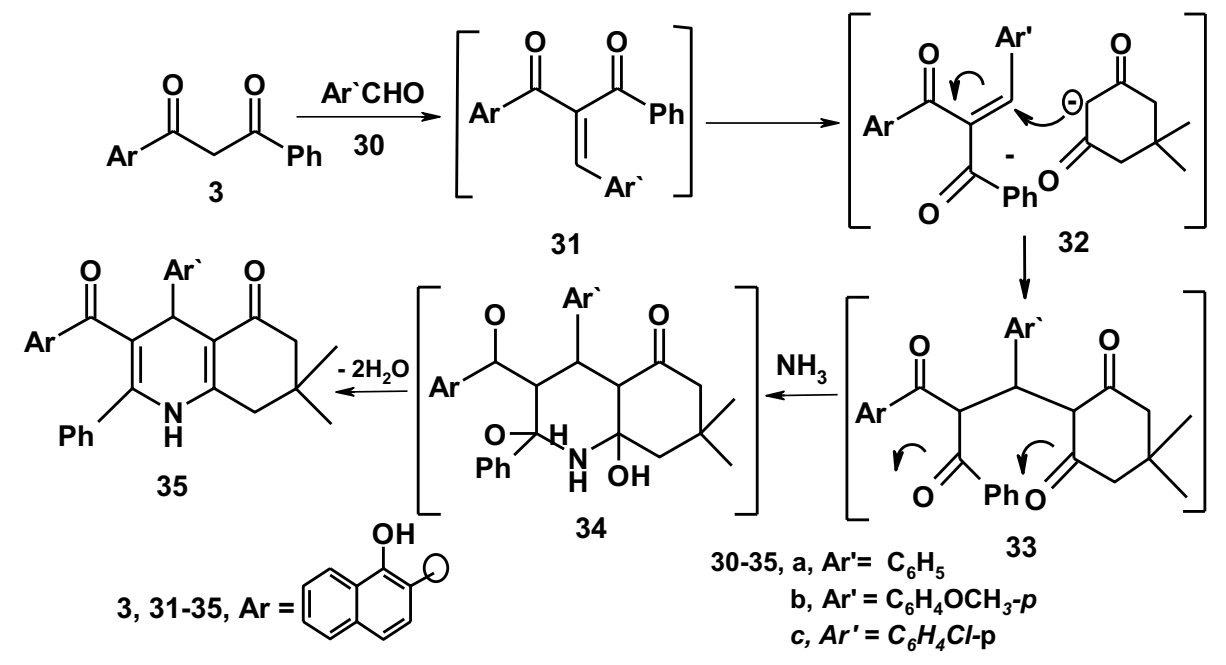

piperidine. The structures of compounds $\mathbf{4 0 a}, \mathbf{b}$ were established based on analytical and spectral data. The products 40a,b are apparently formed via a Michael type addition of the active methylene group in compound $\mathbf{3}$ to the activated double bond in arylidinemalononitrile 36a,b to form the non-isolable intermediate $\mathbf{3 9}$ through an intramolecular cyclization and subsequent tautomerization to give $\mathbf{4 0 a}, \mathbf{b}$. Also, compound $\mathbf{3}$ was reacted with arylidinecyanothioacetamide to yield the acceptable pyridinethione derivatives 45a-c. We first assumed that the reaction product is formed via addition of active methylene to $\alpha, \beta$-unsaturated linkage and subsequent water elimination from carbonyl benzoyl group to yield a cyclic intermediate $\mathbf{4 4}$ which aromatized by loss of $\mathrm{H}_{2}$ to yield the pyridinethione $\mathbf{4 5}$ as demonstrated in (Scheme 7). Confirmation of pyridinethiones $\mathbf{4 5}$ based on its compatible spectroscopic data. Thus, the ${ }^{1} \mathrm{H}-\mathrm{NMR}$ spectrum of compound $\mathbf{4 5} \mathrm{b}$ for example showed a singlet signal at $\delta=3.87 \mathrm{ppm}$ assigned for $\mathrm{OCH}_{3}$, a singlet signal at $\delta=8.74 \mathrm{ppm}$ assigned to $\mathrm{OH}$, a singlet signal at $\delta=9.87 \mathrm{ppm}$ assigned for $\mathrm{NH}$ group in addition to a multiplet signals at $\delta=7.12-8.73 \mathrm{ppm}$ assigned to aromatic protons [34, 39, 40].

Similarly, The reaction of compound $\mathbf{3}$ with cyclopentylidenecynothiocetamide and cyclohexyliden-cynothioacetamide 46a,b yield the azaspiro derivatives 49a,b through the intermediates 47 and 48 [41] as demonstrated in (Scheme 8). Establishing the spiro derivatives was based on its compatible spectroscopic data and elemental analyses.

Coupling of propane-1,3-dione derivative 3 with diazotized aromatic amines in ethanol buffered with sodium acetate at $0-5{ }^{\circ} \mathrm{C}$ afforded the aryl hydrazones 51a-c. The aryl hydrazones were established based on its compatible spectroscopic data and elemental analyses. Condensation of 51 with malononitrile proceeded very readily by fusion in the presence of ammonium acetate to yield the pyridazine derivatives 54 a-c. Compounds 54a-c were established based on spectral data (IR, ${ }^{1} \mathrm{H}-\mathrm{NMR}$ and mass spectra) and

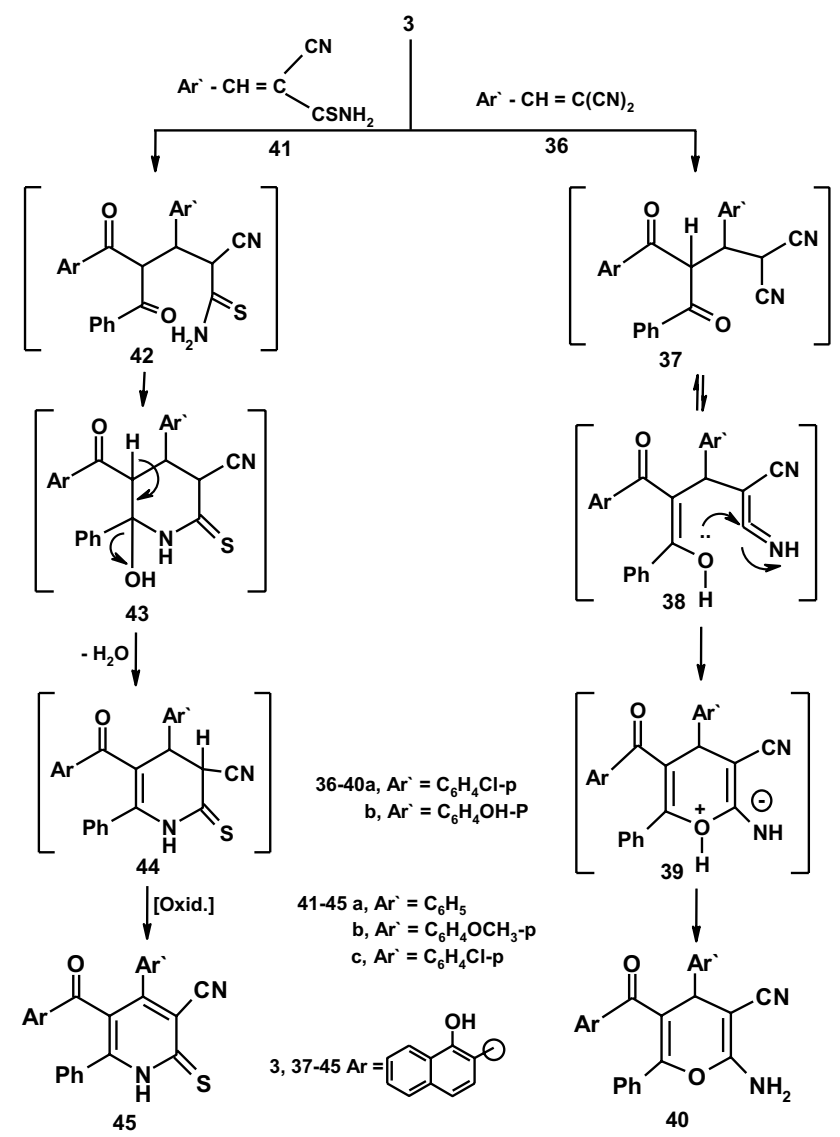

Scheme 7 Reaction of 1,3-diketone with some electrophilic reagents

elemental analyses. Thus, the ${ }^{1} \mathrm{H}-\mathrm{NMR}$ spectrum of $\mathbf{5 4 a}$ for example revealed a singlet signal at $\delta=3.99 \mathrm{ppm}$ assigned to $\mathrm{OCH}_{3}$, a singlet signal at $\delta=8.71 \mathrm{ppm}$ assigned to $\mathrm{OH}$ group in addition to a multiplet signals at $\delta=6.68-8.25 \mathrm{ppm}$ corresponding to aromatic protons and $\mathrm{NH}$. Also, the mass spectrum of the same compound revealed a molecular ion 
Scheme 8 The synthetic route of compound 49

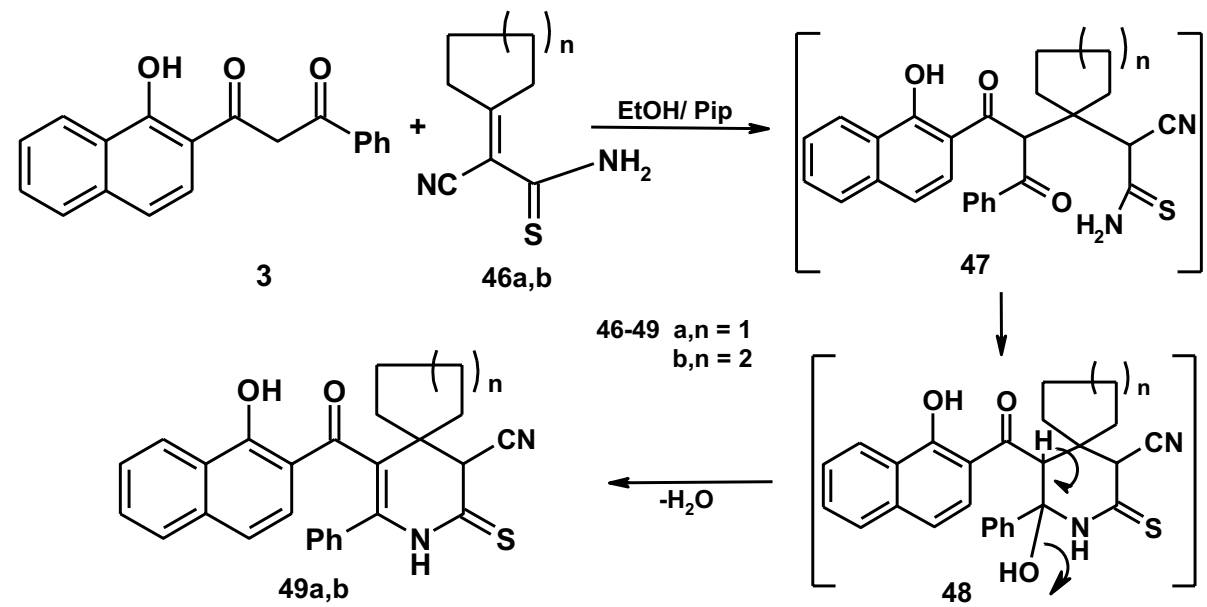

peak at $472\left(\mathrm{M}^{+}\right)$corresponding to the molecular formula $\mathrm{C}_{29} \mathrm{H}_{20} \mathrm{~N}_{4} \mathrm{O}_{3}$ and a number of fragments which agree with the proposed structure [42] (Scheme 9).

\section{In vitro antimicrobial activity}

The newly synthesized compounds have been screened for antibacterial activity against some species of Gram-positive bacteria (Staphylococcus aureus and Bacillus subtilis) and Gram-negative bacteria (Escherichia coli and Pseudomonas aeuroginosa). Anti-fungal activities of the compounds were tested against yeast and mycelial fungi; Candida albicans and Aspergillus flavus, respectively. Each tested compound was dissolved in DMSO making a solution concentration of $1.00 \mathrm{mg} / \mathrm{mL}$ and loaded separately in paper disks of Whatman filter paper with equal diameter size $(10 \mathrm{~mm})$, Paper disks were sterilized in an autoclave. The paper disks loaded with the desired concentration of the complex solution, were placed aseptically in the petri dishes containing nutrient agar medium (agar $20 \mathrm{~g}+$ beef extract $3 \mathrm{~g}+$ peptone $5 \mathrm{~g}$ ) inoculated with Staphylococcus aureus, Bacillus subtilis, Escherichia coli, Pseudomonas aeuroginosa, Candida albicans and Aspergillus flavus. The petri dishes were incubated at $36^{\circ} \mathrm{C}$. The inhibition zones were recorded after $24 \mathrm{~h}$ of incubation in case of bacteria and yeast and after 5-6 days in case of mycelial fungi. Each treatment was replicated three times [43, 44]. Ampicillin and clotrimazole, were used as a common standard antibiotic and antifungal agents, respectively. They prepared using the same procedure as above at the same concentration and solvents. The \% activity index was calculated for the tested compounds by using the given formula in Eq. (1).

$\%$ Activity index $=\frac{\text { Zone of inhibition by test compound (diameter })}{\text { Zone of inhibition by standard (diameter) }} \times 100$

Scheme 9 Synthetic route to pyridaznes

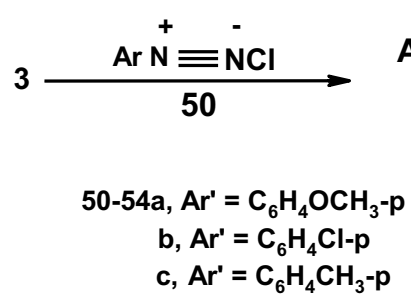<smiles>CCC(=O)C(N=N[Ga])C(=O)c1ccccc1</smiles><smiles>O=C(C(=NNC1CCCCC1)C(=O)c1ccccc1)c1ccccc1</smiles>

3, 51-54, $\mathrm{Ar}=$<smiles>O=C1C=Cc2ccccc2C1O</smiles>
$\downarrow$<smiles>CCCCCCCc1c(-c2ccccc2)nn([Ga])c1C#N</smiles>

54<smiles>N#CC1C(=N)N([Ga])N=C(C(=O)Br)C1(O)c1ccccc1</smiles>

53

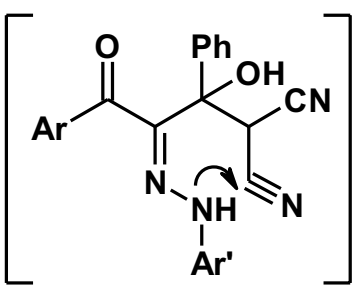

52 


\section{Minimum inhibitory concentration (MIC) measurement}

The minimum inhibitory concentration (MIC) was determined using the disk diffusion technique by preparing disks containing $1.9-1000 \mu \mathrm{g} / \mathrm{mL}$ of each compound against Gram-positive bacteria (Staphylococcus aureus, Bacillus subtilis) and Gram-negative bacteria (Escherichia coli, Pseudomonas aeuroginosa). The anti-fungal activities of the compounds were tested against two fungi Candida albicans and Aspergillus flavus. The twofold dilutions of the solution were prepared. The microorganism suspensions at $10 \mathrm{CFU} / \mathrm{mL}$ (colony forming unit $/ \mathrm{mL}$ ) concentration were inoculated to the corresponding wells. The plates were incubated at $36{ }^{\circ} \mathrm{C}$ for $24 \mathrm{~h}$ for the bacteria. The standard antibiotic ampicillin and antifungal clotrimazole was also recorded using the same procedure as above at the same concentration and solvents. At the end of the incubation period, the minimum inhibitory concentrations (MIC) values were recorded as the lowest concentration of the substance that had no visible turbidity. Control experiments with DMSO and uninoculated media were run parallel to the test compounds under the same condition. Tables 1 and 2 illustrated the results of antimicrobial and antifungal activity and it's MIC. The results which are illustrated in Table 1 showed that most of tasted compounds were active against most of micro-organisms used. Both of compounds $\mathbf{4 5 c}$ and $\mathbf{5}$ showed no antibacterial or antifungal activity. On the other side each of compound 29 and 54a showed maximum antibacterial and antifungal activity. Compound 51a has no antibacterial activity against Gram-negative bacteria only, although it have broad spectrum antibacterial activity against Gram-positive bacteria and antifungal activity against $C$. albicans and A. flavus. On the other hands, compound $\mathbf{2 3}$ showed narrow spectrum antibacterial activity against $P$. aeuroginosa (a Gram-negative bacteria) and S. aureus (a Grampositive bacteria) and revealed no antibacterial activity against E. coli (a Gram-negative bacteria) and B. subtilis (a Gram-positive bacteria), but in case of compound $40 \mathrm{~b}$ it has no antibacterial activity against $B$. Subtilis only and has narrow range spectrum as antibacterial agent against $S$. aureus, E. Coli and P. aeuroginosa with also small rang spectrum antifungal activity. All the other compounds (3, 35b, 26, 35c, 35a, 40a, 10, 16a, 14, and 49a) indicated wide range spectrum antibacterial and antifungal activity.

From Table 2, we observed that compounds 29, 35a, 10, 54a and 16a showed the lowest minimum inhibitory concentrations (MIC) for most tested bacteria and fungi, while compounds 40a, 40b, 35c and 49a exhibited high concentrations of MIC as compared with standard antimicrobial agents used.
Structure-activity relationship: By analyzing the previous results, it is noted that the substitutes do not play a clear role in the biological activity. However, in most of the results it was observed that the compounds that contain electronwithdrawing groups have a higher biological activity than the compounds that contain electron-donating groups and that the biological activity depends on the formation of the new fused rings and the type of strains chosen from bacteria and fungi.

\section{Conclusion}

In conclusion, compounds $\mathbf{3}$ and $\mathbf{5}$ were used as efficient precursors for the synthesis of new heterocycles including $\alpha$-naphthol moiety with expected biological activities.

\section{Experimental}

The melting points, the elemental analyses and the spectral data were recorded as reported in reference [29].

\section{General procedure of the synthesis of 1-(1-hydrox- ynaphthalen-2-yl)-3-phenyl-propane-1,3-dione (3)}

A mixture of $\alpha$-naphthol $1(0.01 \mathrm{~mol}, 1.44 \mathrm{~g})$, ethyl benzoylacetate $2(0.01 \mathrm{~mol}, 1.92 \mathrm{~g})$ and zinc chloride $(0.5 \mathrm{gm})$ was exposed to microwave irradiation (Microwave assisted synthesis was performed on a CEM Microwave synthesizer, the irradiation power was $200 \mathrm{~W}$ as the maximum level of irradiation and a maximum level of internal vessel pressure at 250 Psi for about $5 \mathrm{~min}$ ), the reaction mixture was allowed to reach room temperature, then diluted with ethanol with stirring and the solid product that formed, was filtrated off and crystallized from ethanol to give (3) as brown crystals: M.P.: $147-149{ }^{\circ} \mathrm{C}$, yield: $2.65 \mathrm{~g}(91 \%)$. IR (KBr) $\left(v_{\max } /\right.$ $\left.\mathrm{cm}^{-1}\right): 3365(\mathrm{OH}), 3061(\mathrm{Ar}-\mathrm{H}), 2924$ (Aliph-H), 1720, $1639(2 \mathrm{C}=\mathrm{O})$. MS (EI, $70 \mathrm{eV}): \mathrm{m} / z(\%)=290\left(\mathrm{M}^{+}\right) .{ }^{1} \mathrm{H}$ NMR (400 MHz, DMSO-d ${ }_{6}$ ): $\delta$ (ppm) 4.49 (s, 2H, $\mathrm{CH}_{2}$ ), 7.20-8.68 (m, $11 \mathrm{H}$, aromatic $\mathrm{H}), 8.69(\mathrm{~s}, 1 \mathrm{H}, \mathrm{OH})$. Anal. Calcd. for $\mathrm{C}_{19} \mathrm{H}_{14} \mathrm{O}_{3}$ (290): C, 78.61; H, 4.86. Found: C, 78.63; H, 4.88 .

\section{Synthesis of 2-((dimethylamino)methylene)-1-(1-hydrox-} ynaphthalen-2-yl)-3-phenyl-propane-1,3-dione (5)

A mixture of $3(0.01 \mathrm{~mol}, 2.9 \mathrm{~g})$ and DMF-DMA $(0.01 \mathrm{~mol}, 1.19 \mathrm{~g})$ in dioxane $(30 \mathrm{ml})$ was heated under reflux for $6 \mathrm{~h}$. The reaction mixture was allowed to cool. The separated solid was filtered off, washed with ethanol and crystallized from ethanol to give (5) as pale brown crystals: M.P.: $173-175{ }^{\circ} \mathrm{C}$, yield: $2.65 \mathrm{~g}(77 \%)$. IR (KBr) 


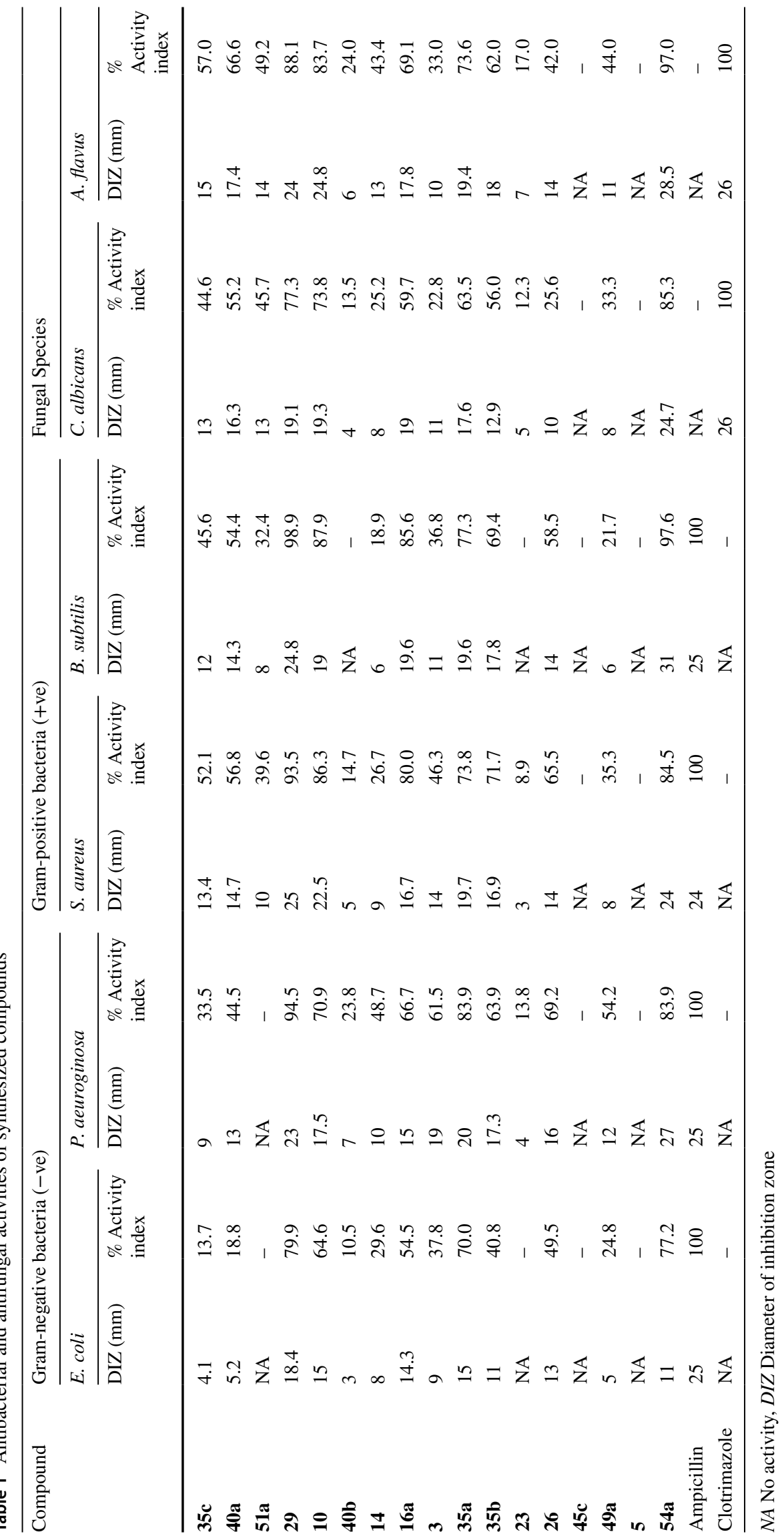


Table 2 Minimum inhibitory concentrations (MIC) for selected compounds

\begin{tabular}{|c|c|c|c|c|c|c|}
\hline \multirow[t]{2}{*}{ Compounds } & \multicolumn{6}{|c|}{ Minimum inhibitory concentration (MIC) of the synthesized compounds $(\mu \mathrm{g} / \mathrm{mL})$} \\
\hline & E. coli & P. aeuroginosa & S. aureus & B. subtilis & C. albicans & A. flavus \\
\hline $35 \mathrm{c}$ & 760 & 530 & 270 & 500 & 65.5 & 50.9 \\
\hline 40a & 780 & 385 & 260 & 500 & 48.9 & 29.4 \\
\hline $51 \mathbf{a}$ & NA & NA & 530 & 740 & 95.7 & 69.5 \\
\hline 29 & 98.7 & 68.5 & 66.5 & 135 & 14.6 & 8.8 \\
\hline 10 & 197.5 & 135 & 90.7 & 189.4 & 22.4 & 9.8 \\
\hline $40 \mathrm{~b}$ & NA & 750 & NA & NA & 510 & 365 \\
\hline 14 & 540 & 260 & 740 & NA & 188.5 & 93.7 \\
\hline $16 \mathbf{a}$ & 188.4 & 125 & 125 & 177.5 & 37.2 & 17.6 \\
\hline 3 & 385 & 187.5 & 375 & 740 & 260 & 187.5 \\
\hline $35 a$ & 145 & 92.7 & 135.7 & 240 & 24.4 & 14.7 \\
\hline $35 b$ & 365 & 197.5 & 177.9 & 240 & 63.5 & 39.2 \\
\hline 23 & NA & NA & NA & NA & 760 & 600 \\
\hline 26 & 240 & 136 & 187.8 & 385 & 260 & 145 \\
\hline $45 c$ & NA & NA & NA & NA & NA & NA \\
\hline $49 a$ & 520 & 260 & 500 & NA & 125 & 97.7 \\
\hline 5 & NA & NA & NA & NA & NA & NA \\
\hline $54 a$ & 125 & 93.7 & 93.7 & 125 & 11.7 & 3.9 \\
\hline Ampicillin & 125 & 187.5 & 93.7 & 187.5 & NA & NA \\
\hline Clotrimazole & NA & NA & NA & NA & 7.8 & 5.8 \\
\hline
\end{tabular}

NA No activity

$\left(v_{\max } / \mathrm{cm}^{-1}\right): 3422(\mathrm{NH}), 3062(\mathrm{Ar}-\mathrm{H}), 2932-2854$ (Aliph$\mathrm{H}), 1723,1636(2 \mathrm{C}=\mathrm{O})$. MS $($ EI, $70 \mathrm{eV}): \mathrm{m} / \mathrm{z}(\%)=345$ $\left(\mathrm{M}^{+}\right) .{ }^{1} \mathrm{H}$ NMR $\left(400 \mathrm{MHz}, \mathrm{DMSO}-\mathrm{d}_{6}\right): \delta 3.00(\mathrm{~s}, 6 \mathrm{H}$, $\left.2 \mathrm{CH}_{3}\right), 7.19$ (s, 1H, CH-oleffinic), 7.64-8.67 (m, $11 \mathrm{H}$, aromatic H), $8.68(\mathrm{~s}, 1 \mathrm{H}, \mathrm{OH}) .{ }^{13} \mathrm{C}$ NMR $(100 \mathrm{MHz}$, DMSO$\left.\mathrm{d}_{6}\right): \delta(\mathrm{ppm}) 44.5,44.5,116.2,122.4,124.3,126.1,126.7$, 127.6, 127.6, 128.1, 128.1, 128.2, 128.6, 129.1, 130.1, 132.4, 132.5, 138.1, 163.2, 166.5, 194.7, 198.0. Anal. calcd for $\mathrm{C}_{22} \mathrm{H}_{19} \mathrm{NO}_{3}(345)$ : C, 76.50; H, 5.54; N, 4.06. Found: C, 76.52; H, 5.56; N, 4.08.

\section{Synthesis of 2-(ethoxymethylene)-1-(1-hydroxynaphtha- len-2-yl)-3-phenylpropane-1,3-dione (6)}

A mixture of $3(0.01 \mathrm{~mol}, 2.9 \mathrm{~g})$ and triethoxy methane $(3 \mathrm{ml})$ in acetic anhydride $(10 \mathrm{ml})$ was heated under reflux for $12 \mathrm{~h}$. The reaction mixture was allowed to cool. The separated solid was filtered off, washed with ethanol and crystallized from ethanol to give (6) as pale brown crystals: M.P.: $120-122{ }^{\circ} \mathrm{C}$, yield: $3.46 \mathrm{~g}(83 \%)$. IR (KBr) $\left(v_{\max } / \mathrm{cm}^{-1}\right): 3426(\mathrm{OH}), 3062(\mathrm{Ar}-\mathrm{H}), 2930$ (Aliph$\mathrm{H}), 1767,1636(2 \mathrm{C}=\mathrm{O})$. MS $($ EI, $70 \mathrm{eV}): \mathrm{m} / z(\%)=346$ $\left(\mathrm{M}^{+}\right) .{ }^{1} \mathrm{H}$ NMR $\left(400 \mathrm{MHz}, \mathrm{DMSO}_{-} \mathrm{d}_{6}\right): \delta(\mathrm{ppm}) 1.11(\mathrm{t}$, $3 \mathrm{H}, \mathrm{CH}_{3}$ ) 4.19 (q, 2H, $\mathrm{CH}_{2}$ ), 6.33 (s, 1H, CH-oleffinic), 7.29-8.23 (m, $11 \mathrm{H}$, aromatic $\mathrm{H}), 8.68(\mathrm{~s}, 1 \mathrm{H}, \mathrm{OH})$. Anal. calcd for $\mathrm{C}_{22} \mathrm{H}_{18} \mathrm{O}_{4}$ (346): C, 76.29; H, 5.24. Found: C, $76.31 ; \mathrm{H}, 5.26$.

\section{Synthesis of 5-(1-hydroxy-2-naphthoyl)-4-phenyl-2-thi- oxo-1,2-dihydropyridine-3-carbonitrile (10)}

A mixture of 5 (0.01 mol, $3.45 \mathrm{~g})$ and cyanothioacetamide $7(0.01 \mathrm{~mol}, 1 \mathrm{~g})$, in presence of sodium ethoxide $(30 \mathrm{ml})$ was heated under reflux for $24 \mathrm{~h}$. The solution was allowed to cool and poured into crushed ice then acidified with $\mathrm{HCl}$. The separated solid was filtered off, washed with water and crystallized from dioxane to give (10) as brown crystals: M.P.: $238-240{ }^{\circ} \mathrm{C}$, yield: $3.35 \mathrm{~g}(87 \%)$. IR (KBr) $\left(v_{\max }\right.$ ' $\left.\mathrm{cm}^{-1}\right)$ : 3447, $3423(\mathrm{NH}), 3062(\mathrm{AR}-\mathrm{H}), 2209(\mathrm{CN}), 1636$ $(\mathrm{C}=\mathrm{O})$ ). MS (EI, $70 \mathrm{eV}): \mathrm{m} / \mathrm{z}(\%)=382\left(\mathrm{M}^{+}\right) .{ }^{1} \mathrm{H}$ NMR (400 MHz, DMSO-d $\left.{ }_{6}\right): \delta(\mathrm{ppm}) 7.20-8.24(\mathrm{~m}, 13 \mathrm{H}$, aromatic $\mathrm{H}$ and $\mathrm{NH}), 8.70$ (s, $1 \mathrm{H}, \mathrm{OH}) .{ }^{13} \mathrm{C} \mathrm{NMR}(100 \mathrm{MHz}$, DMSO- $\left.\mathrm{d}_{6}\right): \delta(\mathrm{ppm}) 107.1,117.0,118.2,122.3,123.2$, $126.3,126.4,126.8,127.3,127.3,127.5,127.5,128.3$, 128.4, 129.1, 130.0, 130.1, 132.2, 144.6, 166.1, 168.0, 168.6, 196.0. Anal. calcd for $\mathrm{C}_{23} \mathrm{H}_{14} \mathrm{~N}_{2} \mathrm{O}_{2} \mathrm{~S}$ (382): C, 72.23; H, 3.69; N, 7.33. Found: C, 72.25; H, 3.71; N, 7.35.

\section{Synthesis of (1-hydroxynaphthalen-2-yl)(3-phenyl-1H-pyra- zol-4-yl)methanone (14)}

Method (A): A mixture of 5 (0.01 mol, $3.45 \mathrm{~g}$ ) and hydrazine hydrate $(10 \mathrm{ml})$ was heated under reflux for $12 \mathrm{~h}$. The reaction mixture was allowed to cool and poured into crushed ice. The separated solid was filtered off, washed with water and crystallized from DMF to give (14). 
Method (B): A mixture of $6(0.01 \mathrm{~mol})$ and hydrazine hydrate $(10 \mathrm{ml})$ was heated under reflux for $12 \mathrm{~h}$. The reaction mixture was allowed to cool and poured into crushed ice. The separated solid was filtered off, washed with water and crystallized from DMF to give (14).

as white crystals: M.P.: $>300{ }^{\circ} \mathrm{C}$, yield: $2.50 \mathrm{~g} \mathrm{(79 \% ).} \mathrm{IR}$ $(\mathrm{KBr})\left(v_{\max } / \mathrm{cm}^{-1}\right): 3300,3228(\mathrm{NH}), 3062(\mathrm{Ar}-\mathrm{H}), 1670$ $(\mathrm{C}=\mathrm{O})$ ). $\mathrm{MS}(\mathrm{EI}, 70 \mathrm{eV}): \mathrm{m} / z(\%)=314\left(\mathrm{M}^{+}\right) .{ }^{1} \mathrm{H} \mathrm{NMR}$ (400 MHz, DMSO-d 6 ): $\delta$ (ppm) 7.22 (s, 1H, CH-pyrazole), 7.31-8.71 (m, 12H, aromatic and $\mathrm{NH}), 8.73(\mathrm{~s}, 1 \mathrm{H}, \mathrm{OH})$. Anal. calcd for $\mathrm{C}_{20} \mathrm{H}_{14} \mathrm{~N}_{2} \mathrm{O}_{2}$ (314): C, 76.42; H, 4.49; N, 8.91. Found: C, 76.44; H, 4.51; N, 8.93 .

\section{General procedure for preparation of compounds (16a,b and 18)}

A mixture of $5(0.01 \mathrm{~mol}, 3.45 \mathrm{~g})$ with urea $(0.01 \mathrm{~mol}$, $0.6 \mathrm{~g})$, thiourea $(0.01 \mathrm{~mol}, 0.76 \mathrm{~g})$ and guanidine hydrochloride $(0.01 \mathrm{~mol}, 0.95 \mathrm{~g})$, in presence of sodium ethoxide $(30 \mathrm{ml})$ was heated under reflux for $24 \mathrm{~h}$. The solutions were allowed to cool and poured into crushed ice then acidified with $\mathrm{HCl}$. The separated solids were filtered off, washed with water and crystallized from the proper solvent to give (16a,b and 18).

\section{5-(1-hydroxy-2-naphthoyl)-4-phenylpyrimidin-2(1H)-one} (16a)

It was obtained as beige crystals from DMF: M.P.: $>300{ }^{\circ} \mathrm{C}$, yield: $2.7 \mathrm{~g}(78 \%)$. IR (KBr) $\left(v_{\max } / \mathrm{cm}^{-1}\right): 3447(\mathrm{OH})$, $3423(\mathrm{NH}), 3061(\mathrm{Ar}-\mathrm{H}), 1740,1641(2 \mathrm{C}=\mathrm{O})$. MS (EI, $70 \mathrm{eV}): m / z(\%)=342\left(\mathrm{M}^{+}\right) .{ }^{1} \mathrm{H}$ NMR $(400 \mathrm{MHz}$, DMSO$\left.\mathrm{d}_{6}\right): \delta(\mathrm{ppm}) 7.22$ (s, 1H, CH-pyrimidine), 7.65-8.70 (m, $12 \mathrm{H}$, aromatic $\mathrm{H}$ and $\mathrm{NH}), 8.71(\mathrm{~s}, 1 \mathrm{H}, \mathrm{OH})$. Anal. calcd for $\mathrm{C}_{21} \mathrm{H}_{14} \mathrm{~N}_{2} \mathrm{O}_{3}$ (342): C, 73.68; H, 4.12; N, 8.18. Found: C,73.70; H, 4.14; N,8.20.

\section{(1-hydroxynaphthalen-2-yl)(4-phenyl-2-thioxo-1,2-dihy- dropyrimidin-5-yl)methanone (16b)}

It was obtained as brown crystals from DMF: M.P.: $>300{ }^{\circ} \mathrm{C}$, yield: $2.8 \mathrm{~g}(78 \%)$. IR (KBr) $\left(v_{\max } / \mathrm{cm}^{-1}\right): 3449(\mathrm{OH}), 3400$ $(\mathrm{NH}), 1645(\mathrm{C}=\mathrm{O})$. MS (EI, $70 \mathrm{eV}): \mathrm{m} / z(\%)=358\left(\mathrm{M}^{+}\right)$. ${ }^{1} \mathrm{H}$ NMR (400 MHz, DMSO-d 6 ): $\delta$ (ppm) 7.19 (s, 1H, CHpyrimidine), 7.59-8.67 (m, 12H, aromatic $\mathrm{H}$ and $\mathrm{NH}), 8.68$ (s, 1H, OH). Anal. calcd for $\mathrm{C}_{21} \mathrm{H}_{14} \mathrm{~N}_{2} \mathrm{O}_{2} \mathrm{~S}$ (358): C, 70.37; H, 3.94; N, 7.82. Found: C, 70.39; H, 3.96; N, 7.84.

\section{(2-amino-4-phenylpyrimidin-5-yl)(1-hydroxynaphtha- len-2-yl)methanone (18)}

It was obtained as brown crystals from dioxane: M.P.: 250-252 ${ }^{\circ} \mathrm{C}$, yield: $2.45 \mathrm{~g}(71 \%)$. IR (KBr) $\left(v_{\max } / \mathrm{cm}^{-1}\right)$ :
3449-3400 (OH, NH $), 1642(\mathrm{C}=\mathrm{O})$. MS (EI, $70 \mathrm{eV}): \mathrm{m} / \mathrm{z}$ $(\%)=341\left(\mathrm{M}^{+}\right) .{ }^{1} \mathrm{H}$ NMR $\left(400 \mathrm{MHz}, \mathrm{DMSO}-\mathrm{d}_{6}\right): \delta(\mathrm{ppm})$ $6.20\left(\mathrm{~s}, 2 \mathrm{H}, \mathrm{NH}_{2}\right), 7.31-8.39(\mathrm{~m}, 12 \mathrm{H}$, aromatic $\mathrm{H}), 8.67(\mathrm{~s}$, $1 \mathrm{H}, \mathrm{OH}) .{ }^{13} \mathrm{C}$ NMR $\left(100 \mathrm{MHz}, \mathrm{DMSO}_{6}\right): \delta$ (ppm) 118.0, $119.3,123.2$, 124.3 124.8, 126.4, 126.4, 126.4, 126.6, $127.6,128.2,128.7,128.9,128.9,130.7,132.7,155.3$, 162.7, 165.8, 166.3, 194.0. Anal. calcd for $\mathrm{C}_{21} \mathrm{H}_{15} \mathrm{~N}_{3} \mathrm{O}_{2}$ (341). Anal. Calcd. for $\mathrm{C}_{21} \mathrm{H}_{15} \mathrm{~N}_{3} \mathrm{O}_{2}$ : C, 73.89; H, 4.43; N, 12.31. Found: C, 73.91; H, 4.45; N, 12.33.

\section{Synthesis of (1-hydroxynaphthalen-2-yl)(3-phenylisoxa- zol-4-yl)methanone (20)}

A mixture of 5 (0.01 mol, $3.45 \mathrm{~g})$, hydroxylamine hydrochloride in ethanol $(30 \mathrm{ml})$ containing anhydrous sodium acetate ( $1 \mathrm{~g}$ ) was heated under reflux for $24 \mathrm{~h}$. The reaction mixture was allowed to cool and poured into cold water $(60 \mathrm{ml})$. The separated solid was filtered off and crystallized from ethanol to give (20) as brown crystals: M.P.: $150-152{ }^{\circ} \mathrm{C}$, yield: $2.25 \mathrm{~g}(71 \%)$. IR (KBr) $\left(v_{\max } / \mathrm{cm}^{-1}\right): 3425(\mathrm{OH}), 3060$ $(\mathrm{Ar}-\mathrm{H}), 1636(\mathrm{C}=\mathrm{O}) . \mathrm{MS}(\mathrm{EI}, 70 \mathrm{eV}): \mathrm{m} / z(\%)=315\left(\mathrm{M}^{+}\right)$. ${ }^{1} \mathrm{H}$ NMR (400 MHz, DMSO-d $\left.)_{6}\right): \delta(\mathrm{ppm}) 7.21(\mathrm{~s}, 1 \mathrm{H}, \mathrm{CH}-$ isoxazole $), 7.31-8.70(\mathrm{~m}, 11 \mathrm{H}$, aromatic $\mathrm{H}), 8.71(\mathrm{~s}, 1 \mathrm{H}$, $\mathrm{OH}$ ). Anal. calcd for $\mathrm{C}_{20} \mathrm{H}_{13} \mathrm{NO}_{3}$ (315): C, 76.18; H, 4.16; N, 4.44\%. Found:C, 76.20; H, 4.18; N, 4.46\%.

\section{Synthesis of (2-(3-Phenylisoxazol-5-yl)naphthalen-1-ol (23)}

A mixture of $3(0.01 \mathrm{~mol})$, hydroxylamine hydrochloride $(0.01 \mathrm{~mol})$ in ethanol $(30 \mathrm{ml})$ containing anhydrous sodium acetate $(1 \mathrm{~g})$ was heated under reflux for $24 \mathrm{~h}$. The reaction mixture was allowed to cool and poured into cold water $(60 \mathrm{ml})$. The separated solid was filtered off and crystallized from ethanol to give (23) as beige crystals: M.P.: 132-134 ${ }^{\circ} \mathrm{C}$, yield: $2.25 \mathrm{~g}(80 \%)$. IR $(\mathrm{KBr})\left(v_{\max } / \mathrm{cm}^{-1}\right)$ : $3382(\mathrm{NH}), 3061$ (Ar-H). MS (EI, $70 \mathrm{eV}): m / z(\%)=287$ $\left(\mathrm{M}^{+}\right) .{ }^{1} \mathrm{H}$ NMR $\left(400 \mathrm{MHz}, \mathrm{DMSO}-\mathrm{d}_{6}\right): \delta(\mathrm{ppm}) 7.21(\mathrm{~s}, 1 \mathrm{H}$, $\mathrm{CH}$ - isoxazole), 7.32-8.54 (m, 11H, aromatic $\mathrm{H}), 8.69$ (s, $1 \mathrm{H}, \mathrm{OH}) ;{ }^{13} \mathrm{C}$ NMR (100 MHz, DMSO-d 6 ) $\delta$ 99.6, 118.7, $120.6,123.5,124.1,126.1,126.3,126.5,126.5,127.3$, $127.5,127.6,127.9,128.8,128.8,132.4,161.0,163.2$, 170.1. Anal. calcd for $\mathrm{C}_{19} \mathrm{H}_{13} \mathrm{NO}_{2}$ (287): C, 79.43; H, 4.56; N, 4.88. Found: C, 79.45; H, 4.58; N, 4.90.

\section{Synthesis of 6-(1-hydroxynaphthalen-2-yl)-2-oxo-4-phe- nyl-1,2-dihydropyridine-3-carbonitrile (26)}

A mixture of $3(0.01 \mathrm{~mol}, 2.90 \mathrm{~g})$, malononitrile $(0.01 \mathrm{~mol}$, $0.66 \mathrm{~g})$ in sodium ethoxide $(30 \mathrm{ml})$ was heated under reflux for $12 \mathrm{~h}$. The reaction mixture was allowed to cool and poured into crushed ice then acidified with $\mathrm{HCl}$. The separated solid was filtered off, washed with water and crystallized from ethanol to give (26) as brown crystals: M.P.: 
163-165 ${ }^{\circ} \mathrm{C}$, yield: $2.35 \mathrm{~g}(69 \%)$. IR $(\mathrm{KBr})\left(v_{\max } / \mathrm{cm}^{-1}\right)$ : $3311,3294,3062,2193,1639 \mathrm{~cm}^{-1}$. MS (EI, $\left.70 \mathrm{eV}\right): \mathrm{m} / \mathrm{z}$

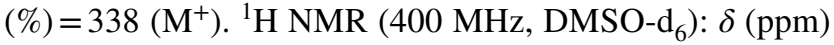
7.16 (s, 1H, CH-Pyridine), 7.51-8.63 (m, 12H, aromatic $\mathrm{H}$ and $\mathrm{NH}), 8.64(\mathrm{~s}, 1 \mathrm{H}, \mathrm{OH}) .{ }^{13} \mathrm{C}$ NMR $(100 \mathrm{MHz}, \mathrm{DMSO}-$ $\left.\mathrm{d}_{6}\right): \delta(\mathrm{ppm}) 108.3,118.3,118.6,120.1,123.4,124.1,125.8$, $126.9,127.1,127.2,127.6,127.6,127.9,127.9,128.3$, $133.9,135.2,153.6,155.2,155.3,157.8,162.3$. Anal. calcd for $\mathrm{C}_{22} \mathrm{H}_{14} \mathrm{~N}_{2} \mathrm{O}_{2}$ (338): C, 78.09; H, 4.17; N, 8.28. Found: $\mathrm{C}$, 78.11; H, 4.19; N, 8.30.

\section{Synthesis of 2-amino-5-(1-hydroxy-2-naphthoyl)-4-phe- nylthiophene-3-carbonitrile (29)}

Equimolar amounts of $\mathbf{3}(0.01 \mathrm{~mol}, 2.90 \mathrm{~g})$, malononitrile and elemental sulfur $(0.01 \mathrm{~mol}, 0.66$ and $0.32 \mathrm{~g})$ in ethanol $(30 \mathrm{ml})$ containing piperidine were refluxed for $15 \mathrm{~h}$, poured onto cold water $(60 \mathrm{ml})$ and acidified with $\mathrm{HCl}$. The solid product thus formed was filtered off and crystallized from ethanol to give (29) as yellow crtstals: M.P.: $130-132{ }^{\circ} \mathrm{C}$, yield: $2.95 \mathrm{~g}(80 \%)$. IR $(\mathrm{KBr})\left(v_{\max } / \mathrm{cm}^{-1}\right): 3421-3400$ $\left(\mathrm{NH}_{2}\right), 3061(\mathrm{Ar}-\mathrm{H}), 2192(\mathrm{CN}), 1639(\mathrm{C}=\mathrm{O})$. MS (EI, $70 \mathrm{eV}): \mathrm{m} / z(\%)=370\left(\mathrm{M}^{+}\right) .{ }^{1} \mathrm{H}$ NMR $(400 \mathrm{MHz}$, DMSO$\left.\mathrm{d}_{6}\right): \delta(\mathrm{ppm}) 7.20-8.68\left(\mathrm{~m}, 13 \mathrm{H}\right.$, aromatic $\mathrm{H}$ and $\left.\mathrm{NH}_{2}\right), 8.69$ (s, $1 \mathrm{H}, \mathrm{OH}$ ). Anal. calcd for $\mathrm{C}_{22} \mathrm{H}_{14} \mathrm{~N}_{2} \mathrm{O}_{2} \mathrm{~S}$ (370): $\mathrm{C}, 71.33$; H, 3.81; N, 7.56. Found:C, 71.35; H, 3.84; N, 7.58.

\section{General procedure for preparation of compounds (35a-c)}

A mixture of 31a-c (which prepared by a mixture of $\mathbf{3}$ and 30a-c in ethanol/piperidine/ refluxing) $(0.01 \mathrm{~mol}, 2.90 \mathrm{~g})$, dimedone $(0.01 \mathrm{~mol}, 1.40 \mathrm{~g})$ and ammonium acetate $(2 \mathrm{gm})$ was fused for $30 \mathrm{~min}$. The reaction mixture was allowed to cool, then triturated with ethanol. The separated solid was filtered off, washed with water and crystallized from the proper solvent to give (35a-c).

\section{3-(1-hydroxy-2-naphthoyl)-7,7-dimethyl-2,4-diphe- nyl-4,6,7,8-tetrahydroquinolin-5(1H)-one (35a)}

It was obtained as yellow crystals from dioxane: M.P.: 280-282 ${ }^{\circ} \mathrm{C}$, yield: $4.30 \mathrm{~g}(86 \%)$. IR $(\mathrm{KBr})\left(v_{\max } / \mathrm{cm}^{-1}\right)$ : 3402, $3400(\mathrm{NH}), 3059(\mathrm{Ar}-\mathrm{H}), 2954-2870$ (Aliph-H), $1642,1620(2 \mathrm{C}=\mathrm{O})$. MS (EI, $70 \mathrm{eV}): m / z(\%)=499\left(\mathrm{M}^{+}\right)$. ${ }^{1} \mathrm{H}$ NMR(400 MHz, DMSO-d $\left.{ }_{6}\right): \delta(\mathrm{ppm}) 0.86\left(\mathrm{~s}, 3 \mathrm{H}, \mathrm{CH}_{3}\right)$, 0.99 (s, 3H, $\left.\mathrm{CH}_{3}\right), 2.73$ (s, $\left.2 \mathrm{H}, \mathrm{CH}_{2}\right), 2.89$ (s, $\left.2 \mathrm{H}, \mathrm{CH}_{2}\right), 4.80$ (s, $1 \mathrm{H}, \mathrm{CH}$-pyridine), $7.14-8.70(\mathrm{~m}, 17 \mathrm{H}$, aromatic $\mathrm{H}$ and $\mathrm{NH}), 8.70$ (s, 1H, OH). Anal. calcd for $\mathrm{C}_{34} \mathrm{H}_{29} \mathrm{NO}_{3}$ (499): $\mathrm{C}$, 81.74; H, 5.85; N, 2.80. Found: C, 81.76; H, 5.87; N, 2.82. 3-(1-hydroxy-2-naphthoyl)-4-(4-methoxyphenyl)-7,7-dimethyl-2-phenyl-4,6,7,8-tetrahydro-quinolin-5(1H)-one (35b)

It was obtained as yellow crystals from dioxane: M.P.: 277-279 ${ }^{\circ} \mathrm{C}$, yield: $4.25 \mathrm{~g}(80 \%)$. IR $(\mathrm{KBr})\left(v_{\max } / \mathrm{cm}^{-1}\right)$ : $3371(\mathrm{OH}), 3255(\mathrm{NH}), 3059(\mathrm{Ar}-\mathrm{H}), 2954-2835$ (Aliph$\mathrm{H}), 1639,1620(2 \mathrm{C}=\mathrm{O})$. MS (EI, $70 \mathrm{eV}): \mathrm{m} / \mathrm{z}(\%)=529$ $\left(\mathrm{M}^{+}\right) .{ }^{1} \mathrm{H}$ NMR $\left(400 \mathrm{MHz}, \mathrm{DMSO}-\mathrm{d}_{6}\right): \delta(\mathrm{ppm})$ 0.82(s, $\left.3 \mathrm{H}, \mathrm{CH}_{3}\right), 1.19\left(\mathrm{~s}, 3 \mathrm{H}, \mathrm{CH}_{3}\right), 2.70\left(\mathrm{~s}, 2 \mathrm{H}, \mathrm{CH}_{2}\right), 2.86(\mathrm{~s}$, $\left.2 \mathrm{H}, \mathrm{CH}_{2}\right), 3.70$ (s, 3H, $\mathrm{OCH}_{3}$ ), 4.49 (s, $1 \mathrm{H}, \mathrm{CH}$-pyridine), 7.21-8.28 (m, 16H, aromatic $\mathrm{H}$ and $\mathrm{NH}), 8.45(\mathrm{~s}, 1 \mathrm{H}, \mathrm{OH})$. ${ }^{13} \mathrm{C}$ NMR (100 MHz, DMSO-d 6 ): $\delta$ (ppm) 29.2, 29.8, 33.8, 41.0, 41.4, 52.3, 57.8, 107.0, 113.2, 116.3, 116.3, 122.0, $123.1,124.3,126.4,126.8,127.2,127.6,127.6,127.6$, $127.8,128.0,128.2,128.9,132.1,132.1,132.7,137.2$, 137.2, 143.6, 150.2, 159.5, 166.0, 193.4, 195.1. Anal. calcd for $\mathrm{C}_{35} \mathrm{H}_{31} \mathrm{NO}_{4}$ (529): C, 79.37; H, 5.90; N, 2.64. Found: C, 79.39; H, 5.92; N, 2.66 .

\section{4-(4-chlorophenyl)-3-(1-hydroxy-2-naphthoyl)-7,7-dime-} thyl-2-phenyl-4,6,7,8-tetra-hydroquinolin-5(1H)-one (35c)

It was obtained as pale yellow crystals from dioxane: M.P.: 290-292 ${ }^{\circ} \mathrm{C}$, yield: $4.30 \mathrm{~g}(83 \%)$. IR $(\mathrm{KBr})\left(v_{\max } / \mathrm{cm}^{-1}\right)$ : $3356(\mathrm{OH}), 3271(\mathrm{NH}), 3059$ (Ar-H), 2954-2870 (Aliph-H), $1643,1620(2 \mathrm{C}=\mathrm{O})$. MS (EI, $70 \mathrm{eV}): m / z(\%)=533\left(\mathrm{M}^{+}\right)$. ${ }^{1} \mathrm{H}$ NMR (400 MHz, DMSO-d 6 ): $\delta$ (ppm) $0.83\left(\mathrm{~s}, 3 \mathrm{H}, \mathrm{CH}_{3}\right)$, $1.20\left(\mathrm{~s}, 3 \mathrm{H}, \mathrm{CH}_{3}\right), 2.70\left(\mathrm{~s}, 2 \mathrm{H}, \mathrm{CH}_{2}\right), 2.89\left(\mathrm{~s}, 2 \mathrm{H}, \mathrm{CH}_{2}\right), 4.49$ (s, $1 \mathrm{H}, \mathrm{CH}$-pyridine), $7.28-8.11(\mathrm{~m}, 16 \mathrm{H}$, aromatic $\mathrm{H}$ and $\mathrm{NH}), 8.50(\mathrm{~s}, 1 \mathrm{H}, \mathrm{OH})$. Anal. calcd for $\mathrm{C}_{34} \mathrm{H}_{28} \mathrm{ClNO}_{3}(533)$ : C, 76.47; H, 5.28; N, 2.62. Found:C, 76.49; H, 5.30; N, 2.64.

\section{General procedure for preparation of compounds $(40 a, b)$}

A mixture of $\mathbf{3}(0.01 \mathrm{~mol}, 2.90 \mathrm{~g})$ and arylidenemalononitriles (36a,b) ( $0.01 \mathrm{~mol}, 1.88$ and $1.70 \mathrm{~g})$ in ethanol $(30 \mathrm{ml})$ containing a catalytic amount of piperidine was heated under reflux for $12 \mathrm{~h}$. The reaction mixture was allowed to cool and poured into crushed ice then acidified with $\mathrm{HCl}$. The separated solid was filtered off, washed with water and crystallized from the proper solvent to give $(\mathbf{4 0 a}, \mathbf{b})$.

2-amino-4-(4-chlorophenyl)-5-(1-hydroxy-2-naphthoyl)-6 -phenyl-4H-pyran-3-carbonitrile (40a)

It was obtained as brown crystals from ethanol: M.P.: $162-164{ }^{\circ} \mathrm{C}$, yield: $4.30 \mathrm{~g}(92 \%)$. IR $(\mathrm{KBr})\left(v_{\max } / \mathrm{cm}^{-1}\right)$ : 3448- 3421 (OH, $\left.\mathrm{NH}_{2}\right), 3063$ (Ar-H), 2929 (Aliph-H), $2191(\mathrm{CN}), 1630(\mathrm{C}=\mathrm{O})$. MS (EI, $70 \mathrm{eV}): \mathrm{m} / \mathrm{z}(\%)=480$ $\left(\mathrm{M}^{+}+2\right) .{ }^{1} \mathrm{H}$ NMR $\left(400 \mathrm{MHz}, \mathrm{DMSO}-\mathrm{d}_{6}\right): \delta(\mathrm{ppm}) 4.40(\mathrm{~s}$, $1 \mathrm{H}, 4 \mathrm{H}$-pyrane), $7.23-8.72\left(\mathrm{~m}, 17 \mathrm{H}\right.$, aromatic $\mathrm{H}$ and $\left.\mathrm{NH}_{2}\right)$, $8.74(\mathrm{~s}, 1 \mathrm{H}, \mathrm{OH}) .{ }^{13} \mathrm{C}$ NMR $\left(100 \mathrm{MHz}, \mathrm{DMSO}_{-} \mathrm{d}_{6}\right): \delta(\mathrm{ppm})$ 
$43.7,60.3,118.9,122.1,123.4,124.2,125.2,125.2,126.2$, $126.8,126.8,126.8,126.9,126.9,127.5,127.5,127.6$, $127.6,128.1,128.2,131.3,131.3,132.6,133.2,135.0$, 140.8, 163.3, 165.2, 193.5. Anal. calcd for $\mathrm{C}_{29} \mathrm{H}_{19} \mathrm{ClN}_{2} \mathrm{O}_{3}$ (478): C, 72.73; H, 4.00; N, 5.85. Found: C, 72.75; H, 4.02; $\mathrm{N}, 5.87$.

2-amino-5-(1-hydroxy-2-naphthoyl)-4-(4-hydroxyphenyl)-6 -phenyl-4H-pyran-3-carbonitrile (40b)

It was obtained as brown crystals from ethanol: M.P.: 200-202 ${ }^{\circ} \mathrm{C}$, yield: $4.30 \mathrm{~g}(90 \%)$. IR $(\mathrm{KBr})\left(v_{\max } / \mathrm{cm}^{-1}\right)$ : 3447-3390 (OH, NH$)_{2}$, $3062(\mathrm{Ar}-\mathrm{H}), 2928$ (Aliph-H), $2196(\mathrm{CN}), 1630(\mathrm{C}=\mathrm{O})$. MS (EI, $70 \mathrm{eV}): \mathrm{m} / \mathrm{z}(\%)=460$ $\left(\mathrm{M}^{+}\right) .{ }^{1} \mathrm{H}$ NMR $\left(400 \mathrm{MHz}, \mathrm{DMSO}-\mathrm{d}_{6}\right): \delta(\mathrm{ppm}) 4.20$ (s, 1H, 4H-pyrane), 6.87 (s, 2H, $\mathrm{NH}_{2}$ ), 6.90-8.71 (m, 15H, aromatic $\mathrm{H}), 8.72(\mathrm{~s}, 1 \mathrm{H}, \mathrm{OH}), 10.00(\mathrm{~s}, 1 \mathrm{H}, \mathrm{OH})$. Anal. calcd for $\mathrm{C}_{29} \mathrm{H}_{20} \mathrm{~N}_{2} \mathrm{O}_{4}$ (460): C, 75.64; H, 4.38; N, 6.08. Found: C, $75.66 ; \mathrm{H}, 4.40 ; \mathrm{N}, 6.10$.

\section{General procedure for preparation of compounds $(45 a-c)$}

A mixture of $3(0.01 \mathrm{~mol}, 2.90 \mathrm{~g})$ and arylidenecyanothioacetamide (41a-c) $(0.01 \mathrm{~mol}, 1.88,2.18$ and $2.22 \mathrm{~g})$ in ethanol $(30 \mathrm{ml})$ containing a catalytic amount of TEA was heated under reflux for $12 \mathrm{~h}$. The reaction mixture was allowed to cool and poured into crushed ice then acidified with $\mathrm{HCl}$. The separated solid was filtered off, washed with water and crystallized from the proper solvent to give $(\mathbf{4 5} \mathbf{a}-\mathbf{c})$.

\section{5-(1-hydroxy-2-naphthoyl)-4,6-diphenyl-2-thioxo-1,2-dihy- dropyridine-3-carbonitrile (45a)}

It was obtained as pale yellow crystals from ethanol: M.P.: 146-148 ${ }^{\circ} \mathrm{C}$, yield: $3.60 \mathrm{~g}(78 \%)$. IR (KBr) $\left(v_{\max } / \mathrm{cm}^{-1}\right): 3444$ $(\mathrm{OH}), 3390(\mathrm{NH}), 3059$ (Ar-H), $2191(\mathrm{CN}), 1620(\mathrm{C}=\mathrm{O})$. MS (EI, $70 \mathrm{eV}): m / z(\%)=458\left(\mathrm{M}^{+}\right) .{ }^{1} \mathrm{H}$ NMR $(400 \mathrm{MHz}$, DMSO-d $\left.{ }_{6}\right): \delta$ (ppm) 7.23-8.73 (m, 17H, aromatic $\mathrm{H}$ and $\mathrm{NH}), 8.74$ (s, 1H, OH). Anal. calcd for $\mathrm{C}_{29} \mathrm{H}_{18} \mathrm{~N}_{2} \mathrm{O}_{2} \mathrm{~S}(458)$ : C, 75.96; H, 3.96; N, 6.11. Found: C, 75.98; H, 3.98; N, 6.13 .

\section{5-(1-hydroxy-2-naphthoyl)-4-(4-methoxyphenyl)-6-phe- nyl-2-thioxo-1,2-dihydro-pyridine-3-carbonitrile (45b)}

It was obtained as pale yellow crystals from ethanol: M.P.: $150-152{ }^{\circ} \mathrm{C}$, yield: $4.00 \mathrm{~g}(82 \%)$. IR (KBr) $\left(v_{\max } / \mathrm{cm}^{-1}\right)$ : 3448, 3387, 3059, 2931, 2194, $1630 \mathrm{~cm}^{-1}$. MS (EI, $\left.70 \mathrm{eV}\right)$ : $m / z(\%)=488\left(\mathrm{M}^{+}\right) .{ }^{1} \mathrm{H}$ NMR $(400 \mathrm{MHz}$, DMSO-d 6$): \delta$ (ppm) $3.87\left(\mathrm{~s}, 3 \mathrm{H}, \mathrm{OCH}_{3}\right), 7.12-8.73(\mathrm{~m}, 15 \mathrm{H}$, aromatic $\mathrm{H}), 8.74$ (s, 1H, OH), 9.87 (s, 1H, NH). ${ }^{13} \mathrm{C} \mathrm{NMR}(100 \mathrm{MHz}$, DMSO-d $\left.{ }_{6}\right): \delta$ (ppm) 57.6, 108.2, 111.9, 118.2, 118.2, 118.8,
$122.3,124.6,124.8,125.2,126.4,126.8,126.8,127.3$, 127.3 , 127.5, 127.6, 128.0, 128.1, 128.7, 132.1, 132.1, 132.7, 135.2, 155.8, 160.8, 163.7, 165.2, 172.6, 193.3. Anal. calcd for $\mathrm{C}_{30} \mathrm{H}_{20} \mathrm{~N}_{2} \mathrm{O}_{3} \mathrm{~S}$ (488): C, 73.75; H, 4.13; N, 5.73. Found: C, 73.77; H, 4.15; N, 5.75.

4-(4-chlorophenyl)-5-(1-hydroxy-2-naphthoyl)-6-phenyl-2-thioxo-1,2-dihydropyridine-3-carbonitrile (45c)

It was obtained as yellow crystals from ethanol: M.P.: 136-138 ${ }^{\circ} \mathrm{C}$, yield: $3.60 \mathrm{~g}(88 \%)$. IR $(\mathrm{KBr})\left(v_{\max } / \mathrm{cm}^{-1}\right)$ : $3390(\mathrm{OH}), 3255(\mathrm{NH}), 3059(\mathrm{Ar}-\mathrm{H}), 2191(\mathrm{CN}), 1635$ $(\mathrm{C}=\mathrm{O})$. MS (EI, $70 \mathrm{eV}): \mathrm{m} / \mathrm{z}(\%)=494\left(\mathrm{M}^{+}+2\right) .{ }^{1} \mathrm{H} \mathrm{NMR}$ (400 MHz, DMSO-d 6 ): $\delta$ (ppm) 7.23-8.73 (m, 16H, aromatic $\mathrm{H}$ and $\mathrm{NH}), 8.74(\mathrm{~s}, 1 \mathrm{H}, \mathrm{OH})$. Anal. calcd for $\mathrm{C}_{29} \mathrm{H}_{17} \mathrm{ClN}_{2} \mathrm{O}_{2} \mathrm{~S}$ (492): C, 70.65; H, 3.48; N, 5.68. Found: C, 70.67; H, 3.50; N, 5.71.

\section{General procedure for preparation of compounds $(49 a, b)$}

A mixture of 3 (0.01 mol, $2.90 \mathrm{~g})$ and 2-cyano-2-cyclopentylidene-ethaneethioamide $46 \mathrm{a}(0.01 \mathrm{~mol}, 1.66 \mathrm{~g})$ or 2-cyano-2-cyclohexylidene-ethaneethioamide $\mathbf{4 6}$ $(0.01 \mathrm{~mol}, 1.88 \mathrm{~g})$ in ethanol $(30 \mathrm{ml})$ containing a catalytic amount of piperidine was heated under reflux for $24 \mathrm{~h}$. The reaction mixture was allowed to cool and poured into crushed ice then acidified with $\mathrm{HCl}$. The separated solid was filtered off, washed with water and crystallized from the proper solvent to give $(\mathbf{4 9 a}, \mathbf{b})$.

10-(1-hydroxy-2-naphthoyl)-9-phenyl-7-thioxo-8-azaspiro[4.5]dec-9-ene-6-carbonitrile (49a)

It was obtained as pale yellow crystals from ethanol: M.P.: 180-182 ${ }^{\circ} \mathrm{C}$, yield: $3.25 \mathrm{~g}(74 \%)$. IR (KBr) $\left(v_{\max } / \mathrm{cm}^{-1}\right): 3387$ (OH), 3248 (NH), 3059 (Ar-H), 2935-2854 (Aliph-H), 2183 $(\mathrm{CN}), 1627(\mathrm{C}=\mathrm{O})$. MS (EI, $70 \mathrm{eV}): \mathrm{m} / z(\%)=440\left(\mathrm{M}^{+}+2\right)$. ${ }^{1} \mathrm{H}$ NMR (400 MHz, DMSO-d 6 ): $\delta(\mathrm{ppm})$ 0.85-1.91 (m, 4H, $2 \mathrm{CH}_{2}$ ), 1.95 (s, 1H, CH-pyridine), 2.00-2.94 (m, 4H, 2CH $\mathrm{CH}_{2}$, 7.14-8.69 (m, 11H, aromatic H), $8.70(\mathrm{~s}, 1 \mathrm{H}, \mathrm{OH})), 9.40(\mathrm{~s}$, $1 \mathrm{H}, \mathrm{NH}) .{ }^{13} \mathrm{C}$ NMR (100 MHz, DMSO-d 6 ): $\delta(\mathrm{ppm}) 27.8$, 27.8, 38.3, 38.3, 39.0, 57.8, 116.2, 119.2, 122.3, 123.3, $123.9,126.1,126.4,126.9,127.3,127.3,127.5,127.8$, $128.3,128.3,128.8,132.5,135.2,155.3,166.7,193.2$, 198.9. Anal. calcd for $\mathrm{C}_{27} \mathrm{H}_{22} \mathrm{~N}_{2} \mathrm{O}_{2} \mathrm{~S}$ (438): $\mathrm{C}, 73.95 ; \mathrm{H}$, 5.06; N, 6.39\%. Found: C, 73.97; H, 5.08; N, 6.41\%.

\section{5-(1-hydroxy-2-naphthoyl)-4-phenyl-2-thi-} oxo-3-azaspiro[5.5] undec-4-ene-1-carbonitrile (49b)

It was obtained as pale yellow crystals from dioxane: M.P.: $278-280{ }^{\circ} \mathrm{C}$, yield: $3.95 \mathrm{~g}(87 \%)$. IR (KBr) $\left(v_{\max } /\right.$ 
$\left.\mathrm{cm}^{-1}\right)$ : $3394(\mathrm{OH}), 3325(\mathrm{NH}), 3062(\mathrm{Ar}-\mathrm{H}), 2931-2854$ (Aliph-H), $2191(\mathrm{CN}), 1643(\mathrm{C}=\mathrm{O})$. MS (EI, $70 \mathrm{eV}): \mathrm{m} / \mathrm{z}$ $(\%)=454\left(\mathrm{M}^{+}+2\right) .{ }^{1} \mathrm{H}$ NMR $\left(400 \mathrm{MHz}\right.$, DMSO-d $\left.{ }_{6}\right): \delta$ (ppm) 0.86-1.02 (m, 4H, 2CH $), 1.76\left(\mathrm{~s}, 2 \mathrm{H}, \mathrm{CH}_{2}\right), 1.96$ (s, 1H, CH-pyridine), 2.00-2.94 (m, 4H, 2 $\left.\mathrm{CH}_{2}\right), 6.70-8.71$ (m, $11 \mathrm{H}$, aromatic $\mathrm{H}), 9.23(\mathrm{~s}, 1 \mathrm{H}, \mathrm{OH}), 9.87(\mathrm{~s}, 1 \mathrm{H}, \mathrm{NH})$. Anal. calcd for $\mathrm{C}_{28} \mathrm{H}_{24} \mathrm{~N}_{2} \mathrm{O}_{2} \mathrm{~S}$ (452): C, 74.31; H, 5.35; N,6.19\%. Found: C, 74.33; H, 5.37; N,6.21\%.

\section{General procedure for preparation of compounds (51a-c)}

A cold suspension of aryl diazonium salts $\mathbf{5 0 a}-\mathbf{c}(0.02 \mathrm{~mol}$, $0.85,0.86$ and $0.77 \mathrm{~g}$ ) (prepared from $0.02 \mathrm{~mol}$ of aromatic amines with the appropriate quantities of sodium nitrite and hydrochloric acid) was gradually added to a cold solution $\left(0-5{ }^{\circ} \mathrm{C}\right)$ of $\mathbf{3}(0.002 \mathrm{~mol}, 1.45 \mathrm{~g})$ in ethanol $(50 \mathrm{ml})$ containing anhydrous sodium acetate $(2 \mathrm{gm})$ with continuous stirring for $1 \mathrm{~h}$. The resulting reaction product was filtered off, washed with water and crystallized from the proper solvent to give compounds $(\mathbf{5 1 a}-\mathbf{c})$.

\section{1-(1-hydroxynaphthalen-2-yl)-2-(2-(4-methoxyphenyl) hydrazono)-3-phenyl propane-1,3-dione (51a)}

It was obtained as brown crystals from ethanol: M.P.: $170-172{ }^{\circ} \mathrm{C}$, yield: $3.45 \mathrm{~g}(81 \%)$. IR (KBr) $\left(v_{\max } / \mathrm{cm}^{-1}\right)$ : $3420(\mathrm{OH}), 3400(\mathrm{NH}), 3062$ (Ar-H), 2930 (Aliph-H), 1724, $1659(2 \mathrm{C}=\mathrm{O})$. MS (EI, $70 \mathrm{eV}): \mathrm{m} / z(\%)=424\left(\mathrm{M}^{+}\right) .{ }^{1} \mathrm{H}$ NMR (400 MHz, DMSO-d $\left.{ }_{6}\right): \delta(\mathrm{ppm}) 3.87$ (s, 3H, $\mathrm{OCH}_{3}$ ), 6.96-8.73 (m, 15H, aromatic $\mathrm{H}), 8.74(\mathrm{~s}, 1 \mathrm{H}, \mathrm{OH}), 11.00(\mathrm{~s}$, $1 \mathrm{H}, \mathrm{NH}$ ). Anal. calcd for $\mathrm{C}_{26} \mathrm{H}_{20} \mathrm{~N}_{2} \mathrm{O}_{4}(424)$ : C, 73.57; H, $4.75 ; \mathrm{N}, 6.60$. Found: C, 73.59; H, 4.77; N, 6.62 .

\section{2-(2-(4-chlorophenyl)hydrazono)-1-(1-hydroxynaphtha- len-2-yl)-3-phenylpropane-1,3-dione (51 b)}

It was obtained as brown crystals from ethanol: M.P.: $161-162{ }^{\circ} \mathrm{C}$, yield: $3.30 \mathrm{~g}(77 \%)$. IR $(\mathrm{KBr})\left(v_{\max } / \mathrm{cm}^{-1}\right): 3449$ $(\mathrm{OH}), 3419(\mathrm{NH}), 3063(\mathrm{Ar}-\mathrm{H}), 1723,1650(2 \mathrm{C}=\mathrm{O})$. MS (EI, $70 \mathrm{eV}): m / z(\%)=430\left(\mathrm{M}^{+}+2\right) .{ }^{1} \mathrm{H}$ NMR $(400 \mathrm{MHz}$, DMSO-d $\left.\mathrm{d}_{6}\right): \delta(\mathrm{ppm}) 7.23-8.71(\mathrm{~m}, 15 \mathrm{H}$, aromatic $\mathrm{H}), 8.72(\mathrm{~s}$, $1 \mathrm{H}, \mathrm{OH}), 12.00(\mathrm{~s}, 1 \mathrm{H}, \mathrm{NH})$. Anal. calcd for $\mathrm{C}_{25} \mathrm{H}_{17} \mathrm{ClN}_{2} \mathrm{O}_{3}$ (428): C, 70.01; H, 4.00; N, 6.53. Found:C, 70.02; H, 4.03; $\mathrm{N}, 6.55$.

\section{1-(1-hydroxynaphthalen-2-yl)-3-phenyl-2-(2-p-tolylhydra- zono) propane-1,3-dione (51c)}

It was obtained as brown crystals from ethanol: M.P.: 166-168 ${ }^{\circ} \mathrm{C}$, yield: $2.90 \mathrm{~g}(71 \%)$. IR (KBr) $\left(v_{\max } / \mathrm{cm}^{-1}\right)$ : 3422, $3400(\mathrm{OH}), 3063(\mathrm{NH}), 2926$ (Aliph-H), 1723, 1650 $(2 \mathrm{C}=\mathrm{O})$. MS $($ EI, $70 \mathrm{eV}): \mathrm{m} / z(\%)=408\left(\mathrm{M}^{+}\right) .{ }^{1} \mathrm{H}$ NMR
(400 MHz, DMSO-d $\left.{ }_{6}\right): \delta(\mathrm{ppm}) 1.91\left(\mathrm{~s}, 3 \mathrm{H}, \mathrm{CH}_{3}\right), 7.14-8.73$ $(\mathrm{m}, 15 \mathrm{H}$, aromatic $\mathrm{H}), 8.74(\mathrm{~s}, 1 \mathrm{H}, \mathrm{OH})), 12.00(\mathrm{~s}, 1 \mathrm{H}, \mathrm{NH})$. Anal. calcd for $\mathrm{C}_{26} \mathrm{H}_{20} \mathrm{~N}_{2} \mathrm{O}_{3}$ (408): C, 76.45; H, 4.94; N, 6.86. Found: C, 76.46; H, 4.96; N, 6.88 .

\section{General procedure for preparation of compounds (54a-c)}

A mixture of compounds 51a-c $(0.001 \mathrm{~mol}, 0.424,0.428$ and $0.408 \mathrm{~g}$ ), ammonium acetate ( $3 \mathrm{gm})$ and malononitrile $(0.001 \mathrm{~mol}, 0.066 \mathrm{~g})$ were fused for $10 \mathrm{~min}$. The solid precipitate so formed was treated with ethanol and filtered out and crystallized from the proper solvent to give $(\mathbf{5 4 a - c})$.

\section{6-(1-hydroxy-2-naphthoyl)-3-im-}

ino-2-(4-methoxyphenyl)-5-phenyl-2,3-dihydropyridazine-4-carbonitrile (54a)

It was obtained as brown crystals from dioxane: M.P.: 230-232 ${ }^{\circ} \mathrm{C}$, yield: $3.75 \mathrm{~g}(79 \%)$. IR $(\mathrm{KBr})\left(v_{\max } / \mathrm{cm}^{-1}\right)$ : $3421(\mathrm{OH}), 3400(\mathrm{NH}), 3065(\mathrm{Ar}-\mathrm{H}), 2928$ (Aliph-H), 2200 $(\mathrm{CN}), 1650(\mathrm{C}=\mathrm{O})$. MS (EI, $70 \mathrm{eV}): \mathrm{m} / z(\%)=472\left(\mathrm{M}^{+}\right) .{ }^{1} \mathrm{H}$ NMR (400 MHz, DMSO-d $\left.{ }_{6}\right): \delta$ (ppm) 3.99 (s, 3H, $\mathrm{OCH}_{3}$ ), 6.68-8.25 (m, 16H, aromatic $\mathrm{H}$ and $\mathrm{NH}), 8.71(\mathrm{~s}, 1 \mathrm{H}, \mathrm{OH})$. Anal. calcd for $\mathrm{C}_{29} \mathrm{H}_{20} \mathrm{~N}_{4} \mathrm{O}_{3}$ (472): C, 73.72; H, 4.27; N, 11.86. Found: C, 73.75; H, 4.29; N, 11.88 .

2-(4-chlorophenyl)-6-(1-hydroxy-2-naphthoyl)-3-imino-5-phenyl-2,3-dihydropyridazine-4-carbonitrile (54b)

It was obtained as brown crystals from dioxane: M.P.: 258-260 ${ }^{\circ} \mathrm{C}$, yield: $3.60 \mathrm{~g}(75 \%)$. IR $(\mathrm{KBr})\left(v_{\max } / \mathrm{cm}^{-1}\right)$ : $3406(\mathrm{OH}), 3400(\mathrm{NH}), 3063(\mathrm{Ar}-\mathrm{H}), 2200(\mathrm{CN}), 1650$ $(\mathrm{C}=\mathrm{O})$. MS $(\mathrm{EI}, 70 \mathrm{eV}): \mathrm{m} / \mathrm{z}(\%)=478\left(\mathrm{M}^{+}+2\right) .{ }^{1} \mathrm{H}$ NMR (400 MHz, DMSO-d $\left.{ }_{6}\right): \delta(\mathrm{ppm}) 6.67-8.25(\mathrm{~m}, 16 \mathrm{H}$, aromatic $\mathrm{H}$ and $\mathrm{NH}), 8.71(\mathrm{~s}, 1 \mathrm{H}, \mathrm{OH})$. Anal. calcd for $\mathrm{C}_{28} \mathrm{H}_{17} \mathrm{ClN}_{4} \mathrm{O}_{2}$ (476): C, 70.52; H, 3.59; N, 11.75\%. Found: C, 70.55; H, $3.63 ; \mathrm{N}, 11.78 \%$.

6-(1-hydroxy-2-naphthoyl)-3-imino-5-phenyl-2-p-tolyl-2,3-dihydropyridazine-4-carbonitrile (54c)

It was obtained as brown crystals from dioxane: M.P.: 272-274 ${ }^{\circ} \mathrm{C}$, yield: $3.85 \mathrm{~g}(84 \%)$. IR $(\mathrm{KBr})\left(v_{\max } / \mathrm{cm}^{-1}\right)$ : 3400, $3385(\mathrm{OH}), 3062(\mathrm{NH}), 2963$ (Aliph-H), $2202(\mathrm{CN})$, 1650 (CO). MS (EI, $70 \mathrm{eV}): \mathrm{m} / \mathrm{z}(\%)=457\left(\mathrm{M}^{+}+1\right) .{ }^{1} \mathrm{H}$ NMR (400 MHz, DMSO-d $\left.{ }_{6}\right): \delta(\mathrm{ppm}) 1.76\left(\mathrm{~s}, 3 \mathrm{H}, \mathrm{CH}_{3}\right)$, 6.67-8.27 (m, 16H, aromatic $\mathrm{H}$ and $\mathrm{NH}), 8.72(\mathrm{~s}, 1 \mathrm{H}, \mathrm{OH})$. Anal. calcd for $\mathrm{C}_{29} \mathrm{H}_{20} \mathrm{~N}_{4} \mathrm{O}_{2}$ (456): C, 76.30; H, 4.42; N, 12.27. Found: C, 76.33; H, 4.45; N, 12.30 . 
Acknowledgements The authors are very grateful to Prof. Dr. A. E. Khodair, Department of Chemistry, Faculty of Science, Suez Canal University, Ismailia, Egypt, for valuable support and reviewing this manuscript, and the authors are very grateful to Department of Microbiology, Faculty of Science, Arish University, Arish, Egypt for performing the antimicrobial evaluation.

Open Access This article is licensed under a Creative Commons Attribution 4.0 International License, which permits use, sharing, adaptation, distribution and reproduction in any medium or format, as long as you give appropriate credit to the original author(s) and the source, provide a link to the Creative Commons licence, and indicate if changes were made. The images or other third party material in this article are included in the article's Creative Commons licence, unless indicated otherwise in a credit line to the material. If material is not included in the article's Creative Commons licence and your intended use is not permitted by statutory regulation or exceeds the permitted use, you will need to obtain permission directly from the copyright holder. To view a copy of this licence, visit http://creativecommons.org/licenses/by/4.0/.

\section{References}

1. El-Helw EAE, Gado MM, El-Ziaty AK (2020) Synthesis and antirotavirus activity of some nitrogen heterocycles integrated with pyrazole scaffold. J Iran Chem Soc 17:1479-1492

2. Wahyuningsih TD, Suma AAT, Astuti E (2019) Synthesis, anticancer activity, and docking study of $\mathrm{N}$-acetyl pyrazolines from veratraldehyde. J Appl Pharm Sci 9(3):14-20

3. Kumar RS, Arif IA, Ahmad A, Idhayadhulla A (2013) Antiinflammatory and antimicrobial activities of novel pyrazole analogues. Saudi J Biol Sci 23:614-620

4. Cherian B, Kumar RA, Vinod B (2020) Pyrazole carbaldehydes as novel anti-inflammatory agents: synthesis and in vitro membrane stabilization method. J Pharm Sci Res 12(2):252-257

5. Kaplancikli ZA, Ozdemir A, Turan-Zitouni G, Altintop MD, Can OD (2010) New pyrazoline derivatives and their antidepressant activity. Eur J Med Chem 45:4383-4387

6. El-Sawy ER, Ebaid MS, Abo-Salem HM, Al-Sehemi AG, Mandour AH (2014) Synthesis, anti-inflammatory, analgesic and anticonvulsant activities of some new 4,6-dimethoxy-5-(heterocycles) benzofuran starting from naturally occurring visnagin. Arabian J Chem 7:914-923

7. Abd El Razik HA, Badr MH, Atta AH, Mouneir SM, Abu-Serie MM (2017) Benzodioxole-pyrazole hybrids as anti-inflammatory and analgesic agents with COX-1,2/5-LOX inhibition and antioxidant potential. Arch Pharm Chem Life Sci 7(350):e1700026

8. Kucukguzel SG, Senkardes S (2015) Recent advances in bioactive pyrazoles. Eur J Med Chem 97:786-815

9. Xu L, Shi L, Qiu S, Chen S, Lin M, Xiang Y, Zhao CH (2019) Design, synthesis, and evalution of cyanopyridines as anti-colorectal cancer agents via inhbiting STAT3 pathway. Drug Des Dev Ther 13:3369-3381

10. Ulloora SH, Shabaraya R, Aamir S, Adhikari AV (2013) New imidazol[1,2-a]pyridines carrying active pharmacophores: synthesis and anticonvulsant studies. Bioorg Med Chem Lett 23:1502-1506

11. Malladi V, Isloor AM, Peethambar SK, Ganesh BM, Goud PS (2012) Synthesis and antimicrobial activity of some new pyrazole containing cyanopyridone derivatives. Der Pharma Chemica 4(1):43-52

12. Paghdar DJ, Akabari JD, Tala SD, Dhaduk MF, Joshi HS (2007) Synthesis of some new thiopyrimidine and oxopyrimidine heterocycles bearing 4-(methylsulfonyl)phenyl nucleus as potent antitubercular and antimicrobial agents. Indian J Heterocycl Chem 17:113-116

13. Faidallah HM, Khan KhA, Asiri AM (2011) Synthesis and characterization of a novel series of benzenesulfonylurea and thiourea derivatives of $2 \mathrm{H}$-pyran and $2 \mathrm{~h}$-pyridine-2-ones as antibacterial, antimycobacterial and antifungal agents. Eur J Chem 2(2):243-250

14. Sangani CHB, Mungra DC, Patel MP, Patel RG (2012) Synthesis and in vitro antimicrobial screening of new pyrano[4,3-b]pyrane derivatives of 1H-pyrazole. Chin Chem Lett 23:57-60

15. Aghajani M, Asghari S, Pasha GHF, Mohseni M (2020) Study of three-componenet reaction of $\alpha$-ketoesters and active methylenes with $\mathrm{OH}$-acids to synthesize new 2 -amino- $4 \mathrm{H}$-pyran derivatives and evaluation of their antibacterial and antioxidant activities. Res Chem Intermed 46:1841-1855

16. Taylor NR, Cleasby A, Singh O, Skarzynski T, Wonacott AJ, Smith PW, Sollis SL, Howes PD, Cherry PC, Bethell R, Colman P, Varghese J (1998) Dihydropyrancarboxamides related to zanamivir: a new series of inhibitors of influenza virus sialidases. 2 . Crystallographic and molecular modeling study of complexes of 4-amino-4H-pyran-6-carboxamides and sialidase from infuenza virus types A and B. J Med Chem 41:798-807

17. Hiramoto K, Nasuhara A, Michikoshi K, Kato T, Kikugawa K (1997) DNA strnd-breaking activity and mutagenicity of 2,3-dihydro-3,5-dihydroxy-6-methyl-4H-pyrn-4-one (DDMP), a maillard reaction product of glucose and glycine. Mutat Res 395:47-56

18. Hadiyal SD, Parmar ND, Kalavadiya PL, Lalpara JN, Joshi HS (2020) Microwave-assisted three-component domino synthesis of polysubstituted $4 \mathrm{H}$-pyran derivaitves and their anticancer activity. Russ J Org Chem 56(4):671-678

19. Hegab MI, Rashad AE, Shamroukh AH, Hamza IA (2006) Synthesis and derivatization of angular 3-chloro-3-chlorosulfenyl naphtho[1,2-b]pyran $(4 \mathrm{H})$-4-ones with evalution of antiviral activity. J Sulfur Chem 27(3):1-12

20. Thakur AS, Verma P, Chandy A (2010) a review on biological profile of pyridazinone containing drugs. Asian J Res Chem 3(2):265-271

21. Alam M, Zaman MS, Alam MM, Arora K, Ahmad A, Husain A (2015) Synthesis and antimicrobial activities of new pyrazolopyridazine derivatives. Int J Pharma Sci Res 6(3):495-501

22. El Ashry ESH, Kassem AA, Ramadan E (2006) Microwave irradiation for accelerating organic reactions-part II: six-, sevenmembered, spiro, and fused heterocycles. Adv Heterocycl Chem 90:1-123

23 El Ashry ESH, Awad LF, Ibrahim EI, Bdeewy OKH (2006) Microwave irradiation for accelerating the synthesis of acridine and xanthene derivatives from dimedone. ARKIVOC 2:178-186

24. Chauhan SS, Joshi YC (2008) Solid phase synthesis of isoxazole derivatives from diaryl 1,3-diketones under microwave irradiation. Rasayan J Chem 1(3):475-480

25. Cirka V, Relich S (2011) Microeave photochrmistry. Application in organic synthesis. Mini Rev Org Chem 8:282-293

26. Ramiz MMM, Abdel Hafiz IS, Abdel Reheim MAM, Gaber HM (2012) Ptrazolones as building blocks in heterocyclic synthesis: synthesis of new pyrazolopyran, pyrazolopyridazine and pyrazole derivatives of expected antifungicidal activity. J Chin Chem Soc 59:72-80

27. Abdel Hafiz IS, Abdel Reheim MAM, Ramiz MMM (2014) Hydantion in heterocyclic synthesis: synthesis of new imidazpyridine, imidazotriazole, pyrazolopurinone, pyranoimidazole, imidazopyridazine and imidazopyrazole derivatives. J Chem Soc Pak 36(5):884-889

28. Abdel Reheim MAM, Abdel Hafiz IS, Elian MA (2016) A simple and convenient synthesis of isolated fused heterocycles based on: 6-phenyl-2-thioxo-2,3-dihydropyrimidin-4(5H)-one and 
5-acetyl-6-phenyl-2-thioxo-2,3-dihydropyrimidn-4(5H)-one. Heterocycles 92(8):1397-1414

29. Abdel Reheim MAM, Abdel Hafiz IS, Abdel Rady HSE (2018) Utility of diketone in heterocyclic synthesis: synthesis of new substituted pyrimidines and fused pyrimidine of potential biosignificant interest. Curr Org Synth 15(8):1171-1181

30. Abdel Reheim MAM, Abdel Hafiz IS, Mohamed S (2016) Utility of $\beta$-diketones in heterocyclic synthesis: synthesis of new tetrahydro-pyrimidinethione, pyrazole, thiophene, dihydropyridine, dihydropyrane, pyridazine derivatives and investigation of their antimicrobial activity. Eur J Chem 7(3):298-308

31. Kini SG, Choudhary S, Mubeen M (2012) Synthesis docking study and anticancer activity of coumarin substituted derivatives of benzothiazole. J Comput Methods Mol Des 2(1):51-60

32. Garazd MM, Garazd YAL, Khilya VP (2005) Neoflavones. 2. Methods for synthesizing and modifying 4-arylcoumarins. Chem Nat Compd 41(3):245-271

33. Pandya AB, Prajapati DG, Pandya SS (2016) Synthesis of novel naphthalene COX inhibitors for anti-inflammatory activity. J Appl Pharm Sci 2(8):226-232

34. Reheim MAM (2016) $\beta$-ketoesters in heterocylic synthesis: synthesis of new dihydropyridine, tetrahydropyrimidine, pyrazole, aminothiophene, pyrazolopyrimidine derivatives, and investigation of their antimicrobial activity. Int J Pharma Sci 6(3):1468-1479

35. Mohareb RM, Mohamed MH (2001) Reaction of 2-amino-3-cyano-4,5,6,7-tetrahydrobenzo-[b]thiophene with ethyl acetoacetate: novel syntheses of pyridines, pyrazoles, and their fused derivatives. Heteroat Chem 12(6):518-526

36. Gein VL, Kazantseva MI, Kurbatova AA, Vahrin MI (2010) Synthesis of 4-aryl-2,7,7-trimethyl-5-oxo-N-phenyl-1,4,5,6,7,8hexahydroquinoline-3-carboxamides. Chem Heterocycl Compd 46(5):629-630
37. Gein VL, Kazantseva MI, Kurbatova AA (2011a) Synthesis of 4, N-diaryl-2,7,7-trimethyl-5-oxo-1,4,5,6,7,8-hexahydro-3-quinolinecarboxamides. Chem Heterocycl Compd 47(6):728-730

38. Gein VL, Kazantseva MI, Kurbatova AA (2011b) synthesis of 4, N-diaryl-2-methyl-5-oxo-1,4,5,6,7,8-hexahydro-quinoline3-carboxamides. Russ J Org Chem 47(6):886-888

39. Hussein AM, Gad-Elkareem MAM, El-Adasy AAM, Othman IM (2009) N-1-naphthyl-3-oxobutanamide in heterocyclic synthesis: a facile synthesis of nicotinamide, thieno[2,3-b]pyridine, and $\mathrm{Bi}$ or tricyclic annulated pyridine derivatives containing naphthyl moiety. Phosphorus Sulfur Silicon 184:2263-2280

40. Aly HM, Kamal MM (2012) efficient one-pot preparation of novel fused chromeno[2,3-d]pyrimidine and pyrano[2,3-d]pyrimidine derivatives. Eur J Med Chem 47:18-23

41. Dyachenko AD, Desenko SM, Dyachenko VD, Rusanov EB (2003) Synthesis and crystal structure of 3-carbamoyl-6-methyl5-phenyl-carbamoyl-2-thioxo-1,2,3,4-tetrahydro-pyridine-4-spirocyclohexane. Chem Heterocycl Compd 39(6):744-748

42. Othman IMM, Nasr HM, Hassan MI (2014) synthesis of some novel pyridazine, thienopyridazine, pyrazolopyridine, pyridopyrazolopyrimidine and pyridopyrazolotriazine derivatives with their antimicrobial activity. Can Chem Trans 2:504-517

43. Murray PR, Baron EJ, Pfaller MA, Tenover FC, Yolken RH (1995) In: Wood GL, Washington JA (eds) Manual of clinical microbiology. The American Society for Microbiology, Washington, DC

44. Jones RN, Barry AL, Gavan TL, Washington IIA (1985) In: Lennette EH, Ballows A, HauslerJr WJ, Shadomy HJ (eds) Manual of clinical microbiology, 4th edn. The American Society for Microbiology, Washington DC

Publisher's Note Springer Nature remains neutral with regard to jurisdictional claims in published maps and institutional affiliations. 